\title{
PILLARED CLAYS AS SUPERIOR CATALYSTS FOR SELECTIVE CATALYTIC REDUCTION OF NITRIC OXIDE
}

\author{
DE-FG22-96PC96206-04
}

\section{SEMI-ANNUAL TECHNICAL PROGRESS REPORT \\ MARCH 1, 1998 - SEPTEMBER 30, 1998}

\author{
Submitted to
}

\author{
Dr. Thomas Dorchak \\ U.S. Department of Energy \\ Federal Energy Technology Center \\ 3610 Collins Ferry Road \\ P.O. Box 880 \\ Morgantown, WV 26507-0880 \\ and \\ AAD Document Control \\ Pittsburgy Energy Technology Center \\ Pittsburgy, PA 15236-0940 \\ by \\ Ralph T. Yang \\ Authors: R.Q. Long and R. T. Yang \\ Department of Chemical Engineering \\ University of Michigan \\ Ann Arbor, MI 48109
}




\begin{abstract}
Selective catalytic reduction (SCR) of $\mathrm{NO}_{\mathrm{x}}$ by hydrocarbons was investigated on $\mathrm{Pt}$ doped MCM-41 and copper ion and/or cerium ion-exchanged Al-MCM-41 in the presence of excess oxygen. It was found that Pt/MCM-41 provided the highest specific NO reduction rates as compared with other Pt doped catalysts reported in the literature, such as $\mathrm{Pt}_{2} \mathrm{Al}_{2} \mathrm{O}_{3}$ and $\mathrm{P} / \mathrm{ZSM}-5$. For different hydrocarbons, the catalytic activity decreased according to the sequence of $\mathrm{C}_{3} \mathrm{H}_{6} \approx \mathrm{C}_{2} \mathrm{H}_{4} \gg \mathrm{C}_{3} \mathrm{H}_{8}>\mathrm{CH}_{4}$. This catalyst was also stable in the presence of $\mathrm{H}_{2} \mathrm{O}$ and $\mathrm{SO}_{2}$. $\mathrm{Cu}$ exchanged $\mathrm{Al}-\mathrm{MCM}-41$ and cerium promoted $\mathrm{Cu}-\mathrm{Al}-$ MCM-41 (i.e., Ce-Cu-Al-MCM-41) were also found to be active in this reaction. Higher $\mathrm{NO}_{\mathrm{x}}$ conversions to $\mathrm{N}_{2}$ were obtained on the Ce-Cu-Al-MCM-41 as compared with Cu-Al-MCM-41. The activity of Ce-Cu-Al-MCM-41 was approximately the same as that of Cu-ZSM-5; but the former had a wider temperature mindow. TPR results indicated that only isolated $\mathrm{Cu}^{2+}$ and $\mathrm{Cu}^{+}$ions were detected in the $\mathrm{Cu}^{2+}$-exchanged $\mathrm{Al}-\mathrm{MCM}-41$ samples, which may play an important role in the selective catalytic reduction of $\mathrm{NO}_{\mathrm{x}}$ to $\mathrm{N}_{2}$. After some cerium ions were introduced into $\mathrm{Cu}-\mathrm{Al}-\mathrm{MCM}-41, \mathrm{Cu}^{2+}$ in the molecular sieve became more easily reducible by $\mathrm{H}_{2}$. This may be related to the increase of catalytic activity of $\mathrm{NO}_{\mathrm{x}}$ reduction by ethylene.
\end{abstract}




\section{Introduction}

Removal of $\mathrm{NO}_{x}\left(\mathrm{NO}+\mathrm{NO}_{2}\right)$ from exhaust gases is a challenging subject which has been extensively studied in recent years. The selective catalytic reduction (SCR) of $\mathrm{NO}_{\mathrm{x}}$ is one of the most effective means. For large power plants, $\mathrm{V}_{2} \mathrm{O}_{5} / \mathrm{TiO}_{2}$ has been the main commercial catalyst for SCR with $\mathrm{NH}_{3}$ for stationary sources [1]. However, for diesel- and gasoline-fueled engines in vehicles, the use of $\mathrm{NH}_{3}$-based SCR technologies is not practical because of the high cost and $\mathrm{NH}_{3}$ handling problems. The three-way catalyst has been used commercially in gasoline engines for reduction $\mathrm{NO}$ to $\mathrm{N}_{2}$ by carbon monoxide and hydrocarbons under rich-burn conditions, but it becomes ineffective in the presence of excess oxygen [2]. The first catalyst found to be active for selective catalytic reduction of NO by hydrocarbons in the presence of excess oxygen was copper exchanged ZSM-5, reported in 1990 by Iwamoto et al.[3] and Held et al.[4]. A large number of catalysts have been found to be active for these reactions since 1990, such as Cu-ZSM-5 [3-6], Co-ZSM-5 and Co-Ferrierite [7-9], Co/Al2O3[10], CeZSM-5 [11], Cu ${ }^{2+}$-exchanged pillared clay [12, 13], Fe-ZSM-5 [14], Pt-ZSM-5 [15], Rh-ZSM-5 [16], $\mathrm{Pt} / \mathrm{Al}_{2} \mathrm{O}_{3}$ [17-19], and supported $\mathrm{Ag}[20]$. Although $\mathrm{Cu}-\mathrm{ZSM}-5$ is very active and the most intensively studied catalyst, it suffers from severe deactivation in engine tests, mainly due to $\mathrm{H}_{2} \mathrm{O}$ and $\mathrm{SO}_{2}[21,22]$. By comparison, Pt-ZSM-5 was found to be more active than Cu-ZSM-5 and Fe-MOR at lower temperatures $\left(127-277^{\circ} \mathrm{C}\right)[14]$ and the catalysts containing Pt were stable in real diesel exhaust [23]. But they produced much $\mathrm{N}_{2} \mathrm{O}$.

MCM-41, a new member of the zeolite family, shows a regular hexagonal array of uniform pore openings with pore dimensions between 1.5 and $10 \mathrm{~nm}$ [24, 25]. Because it has high thermal stability, high BET surface areas and large pore volumes, MCM-41 has already attracted considerable interests in recent years. It has been studied as catalysts, support and sorbents[26]. Corma and co-workers [27] reported a good catalytic activity for MCM-41 in selective oxidation of hex-1-ene with $\mathrm{H}_{2} \mathrm{O}_{2}$, and norbornene with terbutylhydroperoxide on Ti-MCM-41 catalyst. Fe-Al-MCM-41 were also reported by Yang et. al. [28] as a good catalyst for selective catalytic reduction of $\mathrm{NO}$ with $\mathrm{NH}_{3}$. In this work, we 
investigated the activity of platinum doped MCM-41 and Cu exchanged Al-MCM-41 catalysts in SCR of NO with methane, ethene, propane and propene in the presence of excess oxygen. The effects of oxygen, water vapor and sulfur dioxide on SCR activity were also studied.

\section{Experimental}

\subsection{Preparation of Pt/MCM-41 catalyst}

Pure silica MCM-41 was synthesized according to the procedure given by Kim et. al. [29]. 30.1 ml sodium silicate solution (containing $14 \%$ of $\mathrm{NaOH}$ and $27 \%$ of $\mathrm{SiO}_{2}$, Aldrich) was dropwise added to a three-neck flask containing a mixture of $41.3 \mathrm{ml}$ cetyltrimethylammonium chloride (CTMACl, $25 \mathrm{wt} \%$ in water, Aldrich), $0.6 \mathrm{ml} 28 \mathrm{wt} \% \mathrm{NH}_{3}$ aqueous solution (J.T. Baker) and deionized water, with constant stirring at room temperature. The resulting gel mixture had the following molar composition: $1 \mathrm{SiO}_{2}$ : $0.166 \mathrm{CTMACl}: 0.388 \mathrm{Na}_{2} \mathrm{O}: 0.0247 \mathrm{NH}_{4} \mathrm{OH}: 40 \mathrm{H}_{2} \mathrm{O}$. After stirring for $1 \mathrm{~h}$, the mixture was heated to $97{ }^{\circ} \mathrm{C}$ for $24 \mathrm{~h}$, then cooled down to room temperature and the $\mathrm{pH}$ was adjusted to 10.2 by adding $2 \mathrm{~N}$ $\mathrm{HNO}_{3}$. The reaction mixture ( $\left.\mathrm{pH}=10.2\right)$ was heated to $97{ }^{\circ} \mathrm{C}$ again for $24 \mathrm{~h}$. This procedure of $\mathrm{pH}$ adjustment and subsequent heating (for $24 \mathrm{~h}$ drration) was repeated twice. Finally, the product was filtered, washed with deionized water, dried at $110{ }^{\circ} \mathrm{C}$ for $12 \mathrm{~h}$ and then calcined at $560{ }^{\circ} \mathrm{C}$ for $10 \mathrm{~h}$ in a flow of air (150 ml/min). 0.5-5 wt\% Pt/MCM-41 catalysts were prepared by using the incipient wetness impregnation method with hydrogen hexachloroplatinate (IV) hydrate (99.9\%, Aldrich) as the platinum precursor. After calcination at $500{ }^{\circ} \mathrm{C}$ for $4 \mathrm{~h}$ in air, the samples were crushed to $60-100$ mesh.

\subsection{Preparation of $\mathrm{Cu}-\mathrm{Al}-\mathrm{MCM}-41$ catalyst}

Fumed silica (99.8\%, Aldrich), tetramethylammonium hydroxide pentahydrate (TMAOH, 97\%, Aldrich), ), 25 wt.\% cetyltrimethylammonium chloride (CTMACl) in water (Aldrich), 
$\mathrm{Al}\left[\mathrm{C}_{2} \mathrm{H}_{5} \mathrm{CH}\left(\mathrm{CH}_{3}\right) \mathrm{O}\right]_{3}(97 \%$, Aldrich) and $\mathrm{NaOH}(98.1 \%$, Fisher) were used as source materials for preparing Al-MCM-41.

The Al-MCM-41 ( $\mathrm{Si} / \mathrm{Al}=10)$ sample was synthesized according to the procedure given by Borade and Clearfield [37]. Solution A was prepared by dissolving $1.325 \mathrm{~g}$ TMAOH in $100 \mathrm{ml}$ deionized water and then adding $5 \mathrm{~g}$ fumed silica. Solution $\mathrm{B}$ was obtained by dissolving $0.72 \mathrm{~g} \mathrm{NaOH}$ in deionized water and adding $25 \mathrm{ml} \mathrm{CTMACl}$ followed by adding $2.19 \mathrm{ml} \mathrm{Al}\left[\mathrm{C}_{2} \mathrm{H}_{5} \mathrm{CH}\left(\mathrm{CH}_{3}\right) \mathrm{O}\right]_{3}$ at room temperature. The two solutions were stirred for 10-15 min, then solution A was added to solution B. The reaction mixture had the following chemical composition $1 \mathrm{SiO}_{2}-0.05 \mathrm{Al}_{2} \mathrm{O}_{3}-0.23 \mathrm{CTMACl}-0.11 \mathrm{Na}_{2} \mathrm{O}-$ 0.089TMAOH- $125 \mathrm{H}_{2} \mathrm{O}$. After being stirred for $15 \mathrm{~min}$, the mixture was transferred into a $250 \mathrm{ml}$ threeneck flask and was then heated at $100{ }^{\circ} \mathrm{C}$ for $48 \mathrm{~h}$. After filtering, the solid was washed, dried and calcined at $560{ }^{\circ} \mathrm{C}$ for $10 \mathrm{~h}$ in a flow of air $(150 \mathrm{ml} / \mathrm{min})$.

The copper and cerium ion-exchanged Al-MCM-41 were prepared by using conventional ion exchange procedure at room temperature. Solutions of $0.02 \mathrm{MCu}\left(\mathrm{NO}_{3}\right)_{2}$ (adjusting $\mathrm{pH}$ value to 4.5 by $2 \mathrm{~N}$ $\mathrm{HNO}_{3}$ ) and $0.02 \mathrm{M} \mathrm{Ce}\left(\mathrm{NO}_{3}\right)_{3}$ were used for exchange. The Ce-Cu-Al-MCM-41 catalyst was obtained from $\mathrm{Cu}^{2+}$ exchange of the Ce-Al-MCM-41 sample; Ce exchange was done first because it was harder than copper exchange. All the exchange processes were repeated three times and each time was carried out for $24 \mathrm{~h}$. After the ion-exchange procedure, all the samples were calcined at $550{ }^{\circ} \mathrm{C}$ in air for $4 \mathrm{~h}$. The $\mathrm{Cu} / \mathrm{Al}$ in the $\mathrm{Cu}-\mathrm{Al}-\mathrm{MCM}-41$ obtained by neutron activation analysis was 0.372 (i.e., $74.4 \%$ ion exchange), and Ce/Al in Ce-Al-MCM-41 was 0.164 (i.e., $49.2 \%$ ion exchange). In Ce-Cu-Al-MCM-41 sample, $\mathrm{Ce} / \mathrm{Al}$ and $\mathrm{Cu} / \mathrm{Al}$ were 0.053 and 0.37 , respectively, i.e., $89.9 \%$ total ion exchange.

\subsection{Characterization of catalyst}


The powder X-ray diffraction (XRD) measurement was carried out with a Rigaku Rotaflex D/Max-C system with $\mathrm{CuK}_{\alpha}(\lambda=0.1543 \mathrm{~nm})$ radiation. The samples were loaded on a sample holder with a depth of $1 \mathrm{~mm}$. XRD patterns were recorded in the ranges of $2 \theta=1-10^{\circ}$ and $30-70^{\circ}$.

A Micromeritics ASAP 2010 micropore size analyzer was used to measure the $\mathrm{N}_{2}$ adsorption isotherm of the samples at liquid $\mathrm{N}_{2}$ temperature $\left(-196{ }^{\circ} \mathrm{C}\right)$. The specific surface areas of the samples were determined from the linear portion of the BET plots $\left(\mathrm{P} / \mathrm{P}_{0}=0.05-0.20\right)$. The pore size distribution was calculated from the desorption branch of the $\mathrm{N}_{2}$ adsorption isotherm using the Barrett-Joyner-Halenda (BJH) Formula, as suggested by Tanev and Vlaev [30], because the desorption branch can provide more information about the degree of blocking than the adsorption branch hence the best results were obtained from the BJH formula. Prior to the surface area and pore size distribution measurements, the samples were dehydrated at $350^{\circ} \mathrm{C}$ for $4 \mathrm{~h}$.

The dispersions of Pt in the Pt/MCM-41 catalysts were measured by $\mathrm{CO}$ chemisorption on a thermogravimetric analyzer (TGA, Cahn 2000 System 113). Prior to CO chemisorption, the samples were first reduced by $\mathrm{H}_{2}\left(5.34 \% \mathrm{H}_{2}\right.$ in $\left.\mathrm{N}_{2}\right)$ at $400{ }^{\circ} \mathrm{C}$ for $5 \mathrm{~h}$ or more, followed by cooloing to room temperature in He flow. Chemisorption of $\mathrm{CO}$ was performed at room temperature (with $1.03 \% \mathrm{CO}$ in $\mathrm{He}$ ). Equilibrium was assumed when no further weight gain was observed. Based on the amount of CO adsorbed and assuming 1:1 ration for $\mathrm{Pt}_{\mathrm{s}}$ : $\mathrm{CO}$, Pt dispersions were obtained.

The reducibility of catalyst was characterized by temperature-programmed reduction (TPR) analysis. In each experiment, $0.1 \mathrm{~g}$ sample was loaded into a quartz reactor and then pretreated in a flow of $\mathrm{He}(40 \mathrm{ml} / \mathrm{min})$ at $400{ }^{\circ} \mathrm{C}$ for $0.5 \mathrm{~h}$. After the sample was cooled down to room temperature in He, the reduction of the sample was carried out from 30 to $700{ }^{\circ} \mathrm{C}$ in a flow of $5.34 \% \mathrm{H}_{2} / \mathrm{N}_{2}(27 \mathrm{ml} / \mathrm{min})$ at 10 ${ }^{\circ} \mathrm{C} / \mathrm{min}$. The consumption of $\mathrm{H}_{2}$ was monitored continuously by a thermal conductivity detector. The water produced during the reduction was trapped in a 5A molecular sieve column.

\subsection{Catalytic Activity}


The SCR activity measurement was carried out in a fixed-bed quartz reactor. The reaction temperature was controlled by an Omega $(\mathrm{CN}-2010)$ programmable temperature controller. The typical reactant gas composition was as follows: 1000 ppm NO, 1000-3000 ppm hydrocarbons $\left(\mathrm{CH}_{4}, \mathrm{C}_{2} \mathrm{H}_{4}, \mathrm{C}_{3} \mathrm{H}_{8}\right.$ and $\mathrm{C}_{3} \mathrm{H}_{6}$ ), $0-7.8 \% \mathrm{O}_{2}, 500$ ppm $\mathrm{SO}_{2}$ (when used), 5\% water vapor (when used), and balance He. The total flow rate was $250 \mathrm{ml} / \mathrm{min}$ (ambient conditions). The premixed gases $\left(1.01 \% \mathrm{NO}\right.$ in $\mathrm{He}, 1.05 \% \mathrm{CH}_{4}$ in $\mathrm{He}, 1.04 \% \mathrm{C}_{2} \mathrm{H}_{4}$ in $\mathrm{He}, 1.07 \% \mathrm{C}_{3} \mathrm{H}_{6}$ in $\mathrm{He}, 0.98 \% \mathrm{C}_{3} \mathrm{H}_{8}$ in $\mathrm{He}$ and $0.99 \% \mathrm{SO}_{2}$ in $\mathrm{He}$ ) were supplied by Matheson Company. The $\mathrm{NO}$ and $\mathrm{NO}_{2}$ concentrations were continuously monitored by a chemiluminescent $\mathrm{NO} / \mathrm{NO}_{x}$ analyzer (Thermo Electro Corporation, Model 10). The other effluent gases were analyzed by a gas chromatograph (Shimadzu, $14 \mathrm{~A}$ ) at $50{ }^{\circ} \mathrm{C}$ with $5 \mathrm{~A}$ molecular sieve column for $\mathrm{O}_{2}$, $\mathrm{N}_{2}, \mathrm{CH}_{4}$ and $\mathrm{CO}$, and Porapak Q column for $\mathrm{CO}_{2}, \mathrm{~N}_{2} \mathrm{O}, \mathrm{C}_{2} \mathrm{H}_{4}, \mathrm{C}_{3} \mathrm{H}_{6}$ and $\mathrm{C}_{3} \mathrm{H}_{8}$. Other details of the SCR reaction system was described elsewhere [31].

\section{Results and Discussion}

\subsection{Pt/MCM-41 catalyst}

The XRD pattem of pure MCM-41 (not shown) consisted of one very strong peak at $2 \theta=2.14^{\circ}$ and three weak peaks at $2 \theta=3.77^{\circ}, 4.31^{\circ}$ and $5.79^{\circ}$, which can be indexed, respectively, to (100), (110), (200) and (210) diffraction peaks characteristic of a hexagonal structure of MCM-41 [24, 25, 29]. According to the value of $d_{100}\left(d_{100}=4.14 \mathrm{~nm}\right)$, the unit cell dimension $(\mathrm{a}=4.78 \mathrm{~nm})$ was calculated by using the formula: $\mathrm{a}=2 \mathrm{~d}_{100} / \sqrt{ } 3$. After platinum dopings on the MCM-41 sample, the XRD patterns were essentially unchanged (Fig.1), indicating that the incipient wetness impregnation process did not alter the framework structure of this zeolite. The platinum metal phase, with peaks at $2 \theta$ of $39.73^{\circ}, 46.24^{\circ}$ and $67.41^{\circ}$, could also be identified in the XRD patterns of the Pt/MCM-41 catalysts. These three peaks were reflections of, respectively, (111), (200) and (220) faces of the cubic platinum metal structure. With increasing amount of platinum, the intensities of these peaks were seen to increase. No platinum oxide 
phase was detected, whose three strongest peaks would have been found at $2 \theta$ of $34.8^{\circ}, 42.5^{\circ}$ and $54.9^{\circ}$. This was most probably due to its good dispersion on the catalysts. The BET specific surface area, pore volume, average pore diameter, platinum dispersion of the Pt/MCM-41 catalysts are summarized in Table 1. The Pt/MCM-41 catalysts were found to have narrow pore size distributions with pore sizes near 3.8 $\mathrm{nm}$, high BET surface areas( $>900 \mathrm{~m}^{2} / \mathrm{g}$ ) and large pore volumes $\left(>1.00 \mathrm{~cm}^{3} / \mathrm{g}\right)$. The Pt dispersion obtained by $\mathrm{CO}$ chemisorption was between $54 \%$ and $24 \%$ on the $0.5-5 \% \mathrm{Pt} / \mathrm{MCM}-41$ catalysts, with higher dispersions for lower Pt amounts.

The catalytic performance of $0.5-5 \% \mathrm{Pt} / \mathrm{MCM}-41$ for the reduction of $\mathrm{NO}$ with $\mathrm{C}_{3} \mathrm{H}_{6}$ is shown in Table 2. At lower temperatures(below $200{ }^{\circ} \mathrm{C}$ ), $\mathrm{NO}$ conversion and $\mathrm{C}_{3} \mathrm{H}_{6}$ conversion were small. With increasing temperature, NO conversion was found to increase at first, passing through a maximum, then decreased at higher temperatures. The maximum NO conversion appeared at the temperature at which propene conversion reached $100 \%$. Carbon dioxide was the only product (beside water) of propene oxidation. The $\mathrm{N}$ balance and $\mathrm{C}$ balance were above $94 \%$ in this work. Similar to other platinum doped or exchanged catalysts reported in the literature, $\mathrm{N}_{2} \mathrm{O}$ was the main product. This may be related to the fact that platinum is a poor $\mathrm{N}_{2} \mathrm{O}$ decomposition catalyst $[19,32]$. When the platinum amount increased from $0.5 \%$ to $5 \%$, the peak $\mathrm{NO}$ conversion temperature decreased from $275{ }^{\circ} \mathrm{C}$ to $250{ }^{\circ} \mathrm{C}$. At high temperatures, the loss of catalytic activity was due to the oxidation of $\mathrm{C}_{3} \mathrm{H}_{6}$ by $\mathrm{O}_{2}$. The turnover frequencies (TOF) for the conversion of $\mathrm{NO}$, defined as the number of $\mathrm{NO}$ molecules converted per surface Pt atom per second, are also given in Table 2. With the increase of platinum amount, the maximum TOF was found to decrease. The steady-state NO reduction rate (mmol/g·h) was calculated as [8]

$$
\mathrm{NO} \text { reduction rate }=-\mathrm{d}[\mathrm{NO}] / \mathrm{dt}=\mathrm{F}_{0} \mathrm{X} / \mathrm{w}
$$

where $\mathrm{F}_{0}$ was inlet molar flow rate of $\mathrm{NO}, \chi$ was $\mathrm{NO}$ conversion and $\mathrm{w}$ was weight of the catalyst. The maximum NO reduction rate on these Pt/MCM-41 catalysts were $3.6-4.3 \mathrm{mmol} / \mathrm{g} \cdot \mathrm{h}$ at 275 or $250{ }^{\circ} \mathrm{C}$, which was higher than $2.8 \mathrm{mmol} / \mathrm{g} \cdot \mathrm{h}$ obtained on $1 \% \mathrm{Pt}_{\mathrm{Al}} \mathrm{O}_{3}$ catalyst [19] under similar conditions. 
Hamada et al[17] reported that the activity for SCR decreased significantly when alumina was replaced by silica as the support for Pt. Pt supported on ZSM-5 also showed SCR activity [33]. However, the Pt was doped on the exterior surface of the ZSM-5 crystals, and hence was not an effective support [34]. This indicates that the nature of the support plays an important role in the activity of NO reduction with hydrocarbon on platinum. The high activity obtained on the Pt/MCM-41 catalysts was likely due to the large pores and high surface area of MCM-41. Pore diffusion limitation is known to be significant for the SCR reaction [28].

It is well known that oxygen is important in SCR reactions of NO both by hydrocarbons [34] and by $\mathrm{NH}_{3}$ [1]. The effect of $\mathrm{O}_{2}$ on $\mathrm{SCR}$ by $\mathrm{C}_{3} \mathrm{H}_{6}$ over $1 \% \mathrm{P} / \mathrm{MCM}-41$ at $250{ }^{\circ} \mathrm{C}$ was studied, and the results are shown in Fig. 2. In the absence of $\mathrm{O}_{2}$, almost no activity was obtained. When $0.5 \%$ of $\mathrm{O}_{2}$ was added to the reactant gas mixture, $\mathrm{NO}$ conversion was found to increase significantly to $88 \%$ and $\mathrm{C}_{3} \mathrm{H}_{6}$ conversion also reached $100 \%$ at the same temperature. After that, NO conversion decreased slightly with the increase of $\mathrm{O}_{2}$ concentration. It is known that reduced platinum atoms play an important role for $\mathrm{NO}$ conversion $[34,35]$. Burch and Watling reported that about $14 \%$ of platinum atoms on the $\mathrm{Pt} \mathrm{Al}_{2} \mathrm{O}_{3}$ catalyst surface were in the reduced form under the reaction conditions and that $\mathrm{NO}$ did not convert to $\mathrm{N}_{2}$ on a completely oxidized, supported platinum catalyst $[18,35]$. In this work, after the Pt/MCM-41 catalysts were calcined at $500^{\circ} \mathrm{C}$ in air $\left(21 \%\right.$ of $\left.\mathrm{O}_{2}\right)$, the platinum metal phase was still detected by XRD. The XRD result combined with the high dispersions were indirect evidence for the high probability that there existed reduced Pt atoms on the surface. The reduced platinum atoms could be the active sites for NO reduction. The role of oxygen was attributed to its reaction with hydrocarbon fragments left on the Pt sites and thus prevention of the deactivation of the active sites by coke formation[34].

In order to compare directly the effect of different hydrocarbons on SCR activity of NO, we also studied the catalytic performance on the $1 \% \mathrm{Pt} / \mathrm{MCM}-41$ sample using $\mathrm{CH}_{4}, \mathrm{C}_{2} \mathrm{H}_{4}$ and $\mathrm{C}_{3} \mathrm{H}_{8}$ as reductants at the same carbon concentration condition, i.e., 3000 ppm of $\mathrm{CH}_{4}, 1500$ ppm of $\mathrm{C}_{2} \mathrm{H}_{4}$ and $1000 \mathrm{ppm}$ of $\mathrm{C}_{3} \mathrm{H}_{8}$, as compared with 1000 ppm of $\mathrm{C}_{3} \mathrm{H}_{6}$. The results are shown in Fig. 3-6. For $\mathrm{CH}_{4}$ and $\mathrm{C}_{3} \mathrm{H}_{8}$, no or little activity for NO reduction was found on the $1 \% \mathrm{Pt} / \mathrm{MCM}-41$ catalyst in the temperature range of 
150-450 ${ }^{\circ} \mathrm{C}$ (Fig. 3 and Fig. 5). At higher temperatures, only a small amount of $\mathrm{CH}_{4}$ was oxidized to $\mathrm{CO}_{2}$ by $\mathrm{O}_{2}$, while a large amount of $\mathrm{C}_{3} \mathrm{H}_{8}$ was converted to $\mathrm{CO}_{2}$ by $\mathrm{O}_{2}$. By comparison, a very high activity was obtained when $\mathrm{C}_{2} \mathrm{H}_{4}$ and $\mathrm{C}_{3} \mathrm{H}_{6}$ were used as the reductants (Fig. 4 and Fig.6). The maximum NO conversion reached $81 \%$ at $225^{\circ} \mathrm{C}$. This indicated that $\mathrm{C}_{2} \mathrm{H}_{4}$ and $\mathrm{C}_{3} \mathrm{H}_{6}$ were excellent reductants but $\mathrm{CH}_{4}$ and $\mathrm{C}_{3} \mathrm{H}_{8}$ were poor reductants for $\mathrm{SCR}$ of $\mathrm{NO}$ over the $\mathrm{P} / \mathrm{MCM}-41$ catalyst. Similar phenomenon was observed on $\mathrm{Pt}^{-} \mathrm{Al}_{2} \mathrm{O}_{3}$ and $\mathrm{Pt} / \mathrm{SiO}_{2}$ catalysts [36]. This difference is related to the nature of these hydrocarbons. Ethene and propene have a $\mathrm{C}=\mathrm{C}$ double bond and are easy to adsorb on platinum atoms and thus result in a high converage of these alkene species. So the surface is readily reduced to Pt atoms. However, methane and propane are saturated hydrocarbons and thus must have the $\mathrm{C}-\mathrm{H}$ bond broken to chemisorb on the Pt surface. So adsorbed oxygen is the predominant surface species [36]. Because the C$\mathrm{H}$ bond energy in the $\mathrm{CH}_{4}$ molecule $(105 \mathrm{kca} / \mathrm{mol})$ is larger than that in $\mathrm{C}_{3} \mathrm{H}_{8}$ molecule $(95 \mathrm{kca} / \mathrm{mol})$, a higher $\mathrm{C}_{3} \mathrm{H}_{8}$ conversion was obtained using $\mathrm{C}_{3} \mathrm{H}_{8}$ as the reductant than that using $\mathrm{CH}_{4}$ as the reductant in the high temperature range. It is not surprising that $\mathrm{Pt}$ and $\mathrm{PtO}$ might have different catalytic properties for SCR reaction of NO on platinum doped catalysts. Ethene and Propene are better reductants than methane and propane on the Pt/MCM-41 catalyst.

The effect of $\mathrm{H}_{2} \mathrm{O}$ and $\mathrm{SO}_{2}$ on SCR activity of $\mathrm{NO}$ with $\mathrm{C}_{3} \mathrm{H}_{6}$ on $1 \%$ Pt/MCM-41 catalyst is shown in Fig.7. The result exhibited that the Pt/MCM-41 catalyst was a stable catalyst. After being on stream for $10 \mathrm{~h}$ at $225^{\circ} \mathrm{C}$, under the conditions of $1000 \mathrm{ppm} \mathrm{NO}, 1000 \mathrm{ppm} \mathrm{C}_{3} \mathrm{H}_{6}, 2 \%$ of $\mathrm{O}_{2}$, He as balance and $250 \mathrm{ml} / \mathrm{min}$ of total flow rate, $\mathrm{NO}$ conversion remained at $80-81 \%$. When $5 \%$ water vapor and $500 \mathrm{ppm} \mathrm{SO}_{2}$ were added to the reactant gas, the catalytic performance remained unchanged in the following $4 \mathrm{~h}$ at $225^{\circ} \mathrm{C}$.

\subsection{Cu-Al-MCM-41 catalyst}

\subsubsection{Characterization of catalyst}


The powder XRD patterns of Al-MCM-41 and ion-exchanged Al-MCM-41 samples are shown in Fig. 8. The pattern of Al-MCM-41 is consistent with that reported previously for the Al-MCM-41 molecular sieve [37] and all XRD peaks can be indexed on a hexagonal lattice with $d_{100}=4.1 \mathrm{~nm}$. According to the value of $d_{100}$, the unit cell dimension $(a=4.7 \mathrm{~nm})$ was calculated by the formula $a=$ $2 \mathrm{~d}_{100}$ 3. After the sample was exchanged with copper ions and/or cerium ions, the shapes of XRD patterns were essentially unchanged, indicating that the ion exchange process did not affect the framework structure of this molecular sieve. No oxide phase $\left(\mathrm{CuO}\right.$ or $\left.\mathrm{Ce}_{2} \mathrm{O}_{3}\right)$ was detected in these samples.

The BET specific surface area, pore volume, average pore diameter of the Al-MCM-41 and ionexchanged Al-MCM-41 samples are summarized in Table 3. These samples were found to have narrow pore size distributions with pore size of ca. $4.2 \mathrm{~nm}$, high BET specific surface areas ( ca. $900 \mathrm{~m}^{2} / \mathrm{g}$ ) and high pore volumes ( $\left.>1.00 \mathrm{~cm}^{3} / \mathrm{g}\right)$.

TPR can be used to identify and quantify the copper species in copper ion-exchanged zeolite [38]. As shown in Fig. 9, no $\mathrm{H}_{2}$ consumption was found on the $\mathrm{Ce}^{3+}$-exchanged Al-MCM-41 sample below $700{ }^{\circ} \mathrm{C}$, indicating that the $\mathrm{Ce}^{3+}$ in the framework of $\mathrm{Al}-\mathrm{MCM}-41$ is very hard to be reduced to lower valence. For $\mathrm{Cu}-\mathrm{Al}-\mathrm{MCM}-41$ and $\mathrm{Ce}-\mathrm{Cu}-\mathrm{Al}-\mathrm{MCM}-41$ samples, the TPR profiles showed two reduction peaks, which suggests a two-step reduction process of isolated $\mathrm{Cu}^{2+}$ species [38]. One peak appeared at a lower temperature, indicating that the process of $\mathrm{Cu}^{2+} \rightarrow \mathrm{Cu}^{+}$occurred. The other peak at a higher temperature suggests that the produced $\mathrm{Cu}^{+}$was further reduced to $\mathrm{Cu}^{0}$. According to these results, we can conclude that no $\mathrm{CuO}$ aggregates existed in the two copper ion-underexchanged Al-MCM-41 samples (i.e., $\mathrm{Cu} / \mathrm{Al}<0.5$ ) because the $\mathrm{CuO}$ aggregates would be reduced to $\mathrm{Cu}^{\circ}$ by $\mathrm{H}_{2}$ in one step at about $230{ }^{\circ} \mathrm{C}$ if they existed in the two samples [38]. This was in line with the above XRD result that no $\mathrm{CuO}$ phase was detected in the two samples. Copper in the $\mathrm{Cu}-\mathrm{Al}-\mathrm{MCM}-41$ and $\mathrm{Ce}-\mathrm{Cu}-\mathrm{Al}-\mathrm{MCM}-41$ mainly existed in the form of isolated copper ions. Delahay et al. also reported that copper was mainly 
present as isolated $\mathrm{Cu}^{2+}$ species in underexchanged $\mathrm{Cu}-\mathrm{Beta}$ and $\mathrm{Cu}-\mathrm{MFI}$ zeolites [38]. The ratios of $\mathrm{H}_{2}$ consumption to $\mathrm{Cu}$ for the second peak $\left(\mathrm{Cu}^{+} \rightarrow \mathrm{Cu}^{0}\right)$ in the two samples were close to 0.5 (Table 3); by comparison, the $\mathrm{H}_{2} / \mathrm{Cu}$ ratios for the first peak $\left(\mathrm{Cu}^{2+} \rightarrow \mathrm{Cu}^{+}\right)$were lower than 0.5 (Table 3). This phenomenon could be accounted for as the result of partial reduction of $\mathrm{Cu}^{2+}$ to $\mathrm{Cu}^{+}$during the course of catalyst preparation (calcination at $550{ }^{\circ} \mathrm{C}$ ) or pretreatment at $400{ }^{\circ} \mathrm{C}$ in a flow of $\mathrm{He}$. In addition, the reduction temperatures of $\mathrm{Ce}-\mathrm{Cu}-\mathrm{Al}-\mathrm{MCM}-41$ were about $20{ }^{\circ} \mathrm{C}$ lower than those of $\mathrm{Cu}-\mathrm{Al}-\mathrm{MCM}-41$ $\left(323{ }^{\circ} \mathrm{C}\right.$ vs. $342{ }^{\circ} \mathrm{C}$ and $540{ }^{\circ} \mathrm{C}$ vs. $561{ }^{\circ} \mathrm{C}$, as shown in Fig. 9 ), suggesting that the $\mathrm{Cu}^{2+}$ and $\mathrm{Cu}^{+}$ions in the former are more easily reduced than those in the latter. This is reasonable because when $\mathrm{Na}^{+}$in the $\mathrm{Al}$ MCM-41 was partially substituted by $\mathrm{Ce}^{3+}$, the positive charges in the framework would increase and thus lead to weaker electrostatic interactions between Al-MCM-41 and the copper ions. As expected, this would also result in a lower $\mathrm{Cu}^{2+} / \mathrm{Cu}^{+}$ratio in the $\mathrm{Ce}-\mathrm{Cu}-\mathrm{Al}-\mathrm{MCM}-41$ than that in the $\mathrm{Cu}-\mathrm{Al}-\mathrm{MCM}-41$ (0.73 vs. 0.80 , as shown in Table 3) after the samples were treated at $400{ }^{\circ} \mathrm{C}$ in $\mathrm{He}$.

\subsection{2 $N O_{x}$ reduction activity of catalyst}

The catalytic performance of the catalysts for SCR reaction of $\mathrm{NO}_{x}$ with $\mathrm{C}_{2} \mathrm{H}_{4}$ as functions of the reaction temperature are summarized in Fig. 10 and Fig. 11. Ce $\mathrm{Ce}^{3+}$-exchanged Al-MCM-41 was found to be inactive in this reaction at $250-600{ }^{\circ} \mathrm{C}$; almost no $\mathrm{NO}_{x}$ was reduced to $\mathrm{N}_{2}$, but some $\mathrm{C}_{2} \mathrm{H}_{4}$ was oxidized to $\mathrm{CO}_{2}$ by $\mathrm{O}_{2}$ at higher temperatures. Over the $\mathrm{Cu}-\mathrm{Al}-\mathrm{MCM}-41$ and $\mathrm{Ce}-\mathrm{Cu}-\mathrm{Al}-\mathrm{MCM}-41$ catalysts, only a small amount of $\mathrm{NO}_{\mathrm{x}}$ was converted to $\mathrm{N}_{2}$ at $250{ }^{\circ} \mathrm{C}$. With the increase of reaction temperature, $\mathrm{NO}_{\mathrm{x}}$ conversion increased, passing through a maximum, then decreased at higher temperatures. No nitrous monoxide and carbon monoxide were detected in the temperature range and $\mathrm{N}_{2}$ was the only product containing nitrogen. The nitrogen balance and carbon balance were both above $95 \%$ in this work. The decrease in $\mathrm{NO}_{\mathrm{x}}$ conversion at higher temperatures was due to the combustion of 
ethylene. $\mathrm{Ce}-\mathrm{Cu}-\mathrm{Al}-\mathrm{MCM}-41$ always showed higher $\mathrm{NO}_{x}$ conversions than $\mathrm{Cu}-\mathrm{Al}-\mathrm{MCM}-41$, indicating that cerium ions played an important promoting effect in the catalyst (because no activity was obtained on Ce-Al-MCM-41 sample). The maximum $\mathrm{NO}_{x}$ conversion reached $38 \%$ at $550{ }^{\circ} \mathrm{C}$ over the $\mathrm{Ce}-\mathrm{Cu}-\mathrm{Al}-$ MCM-41 catalyst, which was about 15\% higher than that over Cu-Al-MCM-41. The ethylene conversion reached $100 \%$ at $500{ }^{\circ} \mathrm{C}$ on $\mathrm{Cu}-\mathrm{Al}-\mathrm{MCM}-41$ catalyst. The conversions of ethylene on $\mathrm{Ce}-\mathrm{Cu}-\mathrm{Al}-\mathrm{MCM}-$ 41 were found to be lower than those on $\mathrm{Cu}-\mathrm{Al}-\mathrm{MCM}-41$ before they reached $100 \%$ (Fig. 11).

It is well known that oxygen is important in the SCR reaction of nitric oxides by hydrocarbons. The effect of $\mathrm{O}_{2}$ concentration on $\mathrm{NO}_{x}$ conversion to $\mathrm{N}_{2}$ was also investigated at $500{ }^{\circ} \mathrm{C}$ on $\mathrm{Ce}-\mathrm{Al}-\mathrm{Cu}-$ MCM-41 catalyst. As shown in Fig. 12, almost no $\mathrm{NO}_{x}$ reacted with ethylene in the absence of $\mathrm{O}_{2}$. After $\mathrm{O}_{2}$ was introduced into the feed mixture, $\mathrm{NO}_{\mathrm{x}}$ conversion was significantly increased. This indicates that oxygen plays an important role for the reduction of $\mathrm{NO}_{x}$ by $\mathrm{C}_{2} \mathrm{H}_{4}$, as we expected. The maximum conversion reached ca. $38 \%$ in the presence of $1-1.6 \% \mathrm{O}_{2}$. After that, $\mathrm{NO}_{\mathrm{x}}$ conversion was found to decrease slightly at higher $\mathrm{O}_{2}$ concentrations. $\mathrm{C}_{2} \mathrm{H}_{4}$ conversion always increased with the increase of $\mathrm{O}_{2}$ concentration.

The effect of $\mathrm{H}_{2} \mathrm{O}$ and $\mathrm{SO}_{2}$ on the catalytic activity of the Ce-Cu-Al-MCM-41 catalyst was also studied in this work. As shown in Fig. 13, the Ce-Cu-Al-MCM-41 was stable in the absence of $\mathrm{H}_{2} \mathrm{O}$ and

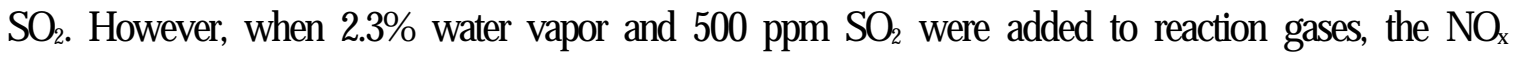
conversion was found to decrease from $36 \%$ to $21-22 \%$ at $500{ }^{\circ} \mathrm{C}$ on the catalyst. No deterioration of catalyst was observed after 30 min of running under these conditions. The effect of $\mathrm{H}_{2} \mathrm{O}$ and $\mathrm{SO}_{2}$ was reversible. When $\mathrm{H}_{2} \mathrm{O}$ and $\mathrm{SO}_{2}$ were removed from the reactants, the catalytic activity was restored.

\subsubsection{Discussion}


When sodium ions in Al-MCM-41 were partially exchanged by copper ions or copper and cerium ions, the $\mathrm{Cu}-\mathrm{Al}-\mathrm{MCM}-41$ and $\mathrm{Ce}-\mathrm{Cu}-\mathrm{Al}-\mathrm{MCM}-41$ catalysts showed a high activity in SCR reaction of $\mathrm{NO}_{\mathrm{x}}$ by ethylene in the presence of excess oxygen. Since the samples without copper (i.e., AlMCM-41 and Ce-Al-MCM-41) showed little or no activity in this reaction, copper ions clearly play an important role for the reduction of $\mathrm{NO}_{\mathrm{x}}$ to $\mathrm{N}_{2}$. Iwamoto and co-workers studied the effect of zeolite structure on the catalytic performance of SCR reaction by comparing $\mathrm{NO}_{\mathrm{x}}$ conversion on different zeolites that were subjected to copper ion exchange [3]. In addition to $\mathrm{Cu}-\mathrm{ZSM}-5(\mathrm{Si} / \mathrm{Al}=11.7), \mathrm{Cu}^{2+}$-exchanged ferrierite $(\mathrm{Si} / \mathrm{Al}=6.2)$, mordenite $(\mathrm{Si} / \mathrm{Al}=5.3)$, Zeolite $\mathrm{L}(\mathrm{Si} / \mathrm{Al}=3.0)$ and Zeolite $\mathrm{Y}(\mathrm{Si} / \mathrm{Al}=2.8)$ were also investigated. They found that the maximum activity was obtained on Cu-ZSM-5 and the lowest activity was on $\mathrm{Cu}-\mathrm{Y}$. The maximum $\mathrm{NO}_{\mathrm{x}}$ conversion (ca. 40\%) was obtained on the Cu-ZSM-5 at 250 ${ }^{\circ} \mathrm{C}$ under the conditions of catalyst $=0.5 \mathrm{~g},[\mathrm{NO}]=1000 \mathrm{ppm},\left[\mathrm{C}_{2} \mathrm{H}_{4}\right]=250 \mathrm{ppm},\left[\mathrm{O}_{2}\right]=2 \%$ and total flowrate $=150 \mathrm{ml} / \mathrm{min}$ [3]. Delahay et al. [38] and Corma et al. [39] also reported that a similar catalytic activity for $\mathrm{NO}_{\mathrm{x}}$ reduction was obtained on Cu-Beta zeolite as compared with Cu-ZSM-5. In this work, we found that $\mathrm{Cu}-\mathrm{Al}-\mathrm{MCM}-41$ was also active for $\mathrm{NO}_{\mathrm{x}}$ reduction to $\mathrm{N}_{2}$ by ethylene in the presence of excess oxygen, but the activity was lower than that of $\mathrm{Cu}-\mathrm{ZSM}-5$. However, on the $\mathrm{Ce}^{3+}$ promoted $\mathrm{Cu}-\mathrm{Al}-$ MCM-41 catalyst, we obtained $38 \% \mathrm{NO}_{\mathrm{x}}$ conversion at $550{ }^{\circ} \mathrm{C}$, which was close to the maximum value on the Cu-ZSM-5 catalyst under the same conditions, as shown in Fig. 10. The maximum $\mathrm{NO}_{\mathrm{x}}$ conversion on the Cu-ZSM-5 was obtained at a lower temperature $\left(300^{\circ} \mathrm{C}\right)$, but $\mathrm{Ce}-\mathrm{Cu}-\mathrm{Al}-\mathrm{MCM}-41$ catalyst had a wider temperature window (i.e., a window of $200{ }^{\circ} \mathrm{C}$ vs. $95{ }^{\circ} \mathrm{C}$ at $\mathrm{NO}_{\mathrm{x}}$ conversion $>25 \%$, as shown in Fig. 10). Like Cu-ZSM-5, the catalytic activity on the Ce-Cu-Al-MCM-41 catalyst decreased in the presence of $\mathrm{H}_{2} \mathrm{O}$ and $\mathrm{SO}_{2}$. The inhibition of catalytic activity by $\mathrm{H}_{2} \mathrm{O}$ and $\mathrm{SO}_{2}$ has been extensively studied on Cu-ZSM-5 catalyst [40-42]. Two reasons were proposed for the deactivation. One was competitive adsorption for the active sites by $\mathrm{H}_{2} \mathrm{O}$ and $\mathrm{SO}_{2}$; the other was framework dealumination of 
ZSM-5 after it was subjected to prolonged exposure to wet exhaust gas at high temperatures [40-42]. The former was reversible; the latter was irreversible. It has been reported that Al-MCM-41 has a high hydrothermal stability [30]. For example, it is stable after heating at $800-900{ }^{\circ} \mathrm{C}$ for $2 \mathrm{~h}$ in the presence of $2.3 \% \mathrm{H}_{2} \mathrm{O} / \mathrm{O}_{2}$ [30]. In this work, the Ce-Cu-Al-MCM-41 catalyst was only exposed to $2.3 \% \mathrm{H}_{2} \mathrm{O}$ at 500 ${ }^{\circ} \mathrm{C}$ for a short time, hence it was impossible for framework dealumination of Al-MCM-41. The reason for deactivation by $\mathrm{H}_{2} \mathrm{O}$ and $\mathrm{SO}_{2}$ was likely due to competitive adsorption on the copper sites by $\mathrm{H}_{2} \mathrm{O}$ and $\mathrm{SO}_{2}$. Our previous study also showed that $\mathrm{SO}_{2}$ could adsorb on the same sites as those by $\mathrm{NO}_{\mathrm{x}}$ over $\mathrm{Cu}^{2+}-$ exchanged pillared clays .

$\mathrm{H}_{2}$-TPR and XRD results showed that the copper in the Cu-Al-MCM-41 and Ce-Cu-Al-MCM41 was mainly present in the form of isolated $\mathrm{Cu}^{2+}$ ions. $\mathrm{Cu}^{2+}$ ions could be partially reduced to $\mathrm{Cu}^{+}$ions when the samples were treated at high temperatures. Almost no $\mathrm{CuO}$ aggregates were detected in the two catalysts. This is consistent with the results obtained in other zeolites (e.g., ZSM-5, Beta zeolite, etc.) that were underexchanged by $\mathrm{Cu}^{2+}$ [38]. The isolated $\mathrm{Cu}^{2+}$ ions may play an important role in the $\mathrm{SCR}$ reaction of $\mathrm{NO}_{\mathrm{x}}$ by ethylene. Several authors have claimed that the active species for $\mathrm{SCR}$ reaction of $\mathrm{NO}_{\mathrm{x}}$ may involve a $\mathrm{Cu}^{2+} / \mathrm{Cu}^{+}$redox cycle in $\mathrm{Cu}^{2+}$-exchanged zeolites $[38,39,43]$. In the presence of hydrocarbon (e.g., $\mathrm{C}_{2} \mathrm{H}_{4}, \mathrm{C}_{3} \mathrm{H}_{6}, \mathrm{C}_{3} \mathrm{H}_{8}$, etc.), the $\mathrm{Cu}^{2+}$ would be reduced to $\mathrm{Cu}^{+}$and then $\mathrm{Cu}^{+}$was oxidized back to $\mathrm{Cu}^{2+}$ by $\mathrm{NO}_{\mathrm{x}}$, thus completing the catalytic cycle. The X-ray absorption near edge structure (XANES) study of Liu and Robota [43] reported that a significant proportion of copper was in the form of $\mathrm{Cu}^{+}$in the presence of propylene (one of the selective reducing agents), even in a large excess of oxygen. Furthermore, the concentration of cuprous ions followed the same trend with temperature as that of $\mathrm{NO}_{\mathrm{x}}$ conversion in the reaction. But the use of non-selective reducing agent (e.g., methane) did not lead to the formation of $\mathrm{Cu}^{+}$. Hence, they concluded that cuprous ions are essential for this reaction. However, more recently, Haller and coworkers [44] used in situ XANES analysis together with comparison of the 
catalytic behaviors of $\mathrm{Cu}-\mathrm{ZSM}-5$ with $\mathrm{CuO} / \mathrm{Al}_{2} \mathrm{O}_{3}$ and $\mathrm{CuO} / \mathrm{SiO}_{2}$ systems and indicated that the rate limiting step of the reaction took place on cupric oxides. They suggested that zeolite supports did not play an essential role in the reaction and that the mechanism might not involve $\mathrm{a} \mathrm{Cu}^{2+} / \mathrm{Cu}^{+}$redox cycle. Their conclusions were based on the fact that the $\mathrm{CuO} / \mathrm{Al}_{2} \mathrm{O}_{3}$ sample showed a higher activity in the reduction of nitric oxides than the Cu-ZSM-5 under their experimental conditions. On the other hand, reports also exist showing that Cu-ZSM-5 (with high exchange, e.g., 80-100\%) was more active than $\mathrm{CuO}$ doped $\mathrm{Al}_{2} \mathrm{O}_{3}$ [34]. In this work, only isolated $\mathrm{Cu}^{2+}$ and $\mathrm{Cu}^{+}$ions were detected in $\mathrm{Cu}-\mathrm{Al}-\mathrm{MCM}-41$ and $\mathrm{Ce}-\mathrm{Cu}-$ MCM-41 catalysts, suggesting that $\mathrm{CuO}$ aggregates may not play an important role in this reaction on these two catalysts. After some cerium ions were introduced into $\mathrm{Cu}-\mathrm{Al}-\mathrm{MCM}-41$, copper ions in the molecular sieve become more easily reducible by $\mathrm{H}_{2}$. This may be related to the increase of catalytic activity of $\mathrm{NO}_{\mathrm{x}}$ reduction by ethylene.

\section{Conclusions}

0.5-5 wt\% Pt/MCM-41 catalysts were prepared and studied for the selective catalytic reduction of $\mathrm{NO}$ with $\mathrm{CH}_{4}, \mathrm{C}_{2} \mathrm{H}_{4}, \mathrm{C}_{3} \mathrm{H}_{6}$ and $\mathrm{C}_{3} \mathrm{H}_{8}$ in the presence of excess oxygen. The catalysts had high $\mathrm{BET}$ surface areas $\left(>900 \mathrm{~m}^{2} / \mathrm{g}\right)$ and large pore volumes $\left(>1.00 \mathrm{~cm}^{3} / \mathrm{g}\right)$. Platinum metal particles were detected in these catalysts at room temperature by XRD. A high activity for NO reduction was obtained when $\mathrm{C}_{2} \mathrm{H}_{4}$ or $\mathrm{C}_{3} \mathrm{H}_{6}$ was used as the reductant and the maximum $\mathrm{NO}$ reduction rate reached $4.3 \mathrm{mmol} / \mathrm{g} \cdot \mathrm{h}$ under the conditions of 1000 ppm NO, $1000 \mathrm{ppm} \mathrm{C}_{3} \mathrm{H}_{6}, 2 \%$ of $\mathrm{O}_{2}$ and $\mathrm{He}$ as balance; but no or little activity was found when $\mathrm{CH}_{4}$ or $\mathrm{C}_{3} \mathrm{H}_{8}$ was used. This difference was related to the different nature of these hydrocarbons. The Pt/MCM-41 catalyst showed a good stability. $\mathrm{H}_{2} \mathrm{O}$ and $\mathrm{SO}_{2}$ did not cause deactivation of the catalyst. 
Besides Pt/MCM-41, Cu-Al-MCM-41 and Ce-Cu-Al-MCM-41 were also found to be active in the reduction of $\mathrm{NO}_{\mathrm{x}}$ to $\mathrm{N}_{2}$ by ethylene in the presence of excess oxygen. Due to the interaction between cerium and copper, the copper ions in the $\mathrm{Ce}-\mathrm{Cu}-\mathrm{Al}-\mathrm{MCM}-41$ could be reduced by $\mathrm{H}_{2}$ more easily than those in the Cu-Al-MCM-41. The former also showed higher $\mathrm{NO}_{\mathrm{x}}$ conversions than the latter in the temperature range of $250-600{ }^{\circ} \mathrm{C}$. In the copper ion-exchanged Al-MCM-41 catalysts, the copper species were mainly present in the form of isolated $\mathrm{Cu}^{2+}$ ions, which may play an important role in the selective catalytic reduction of $\mathrm{NO}_{x}$ to $\mathrm{N}_{2} . \mathrm{H}_{2} \mathrm{O}$ and $\mathrm{SO}_{2}$ caused some deactivation of the catalyst, but the deactivation was reversible.

\section{References:}

[1] H. Bosch and F. Janssen, Catal. Today, 2 (1988) 369.

[2] B.K. Cho, J. Catal., 142 (1993) 418.

[3] M. Iwamoto, "Symposium on Catalytic Technology for Removal of Nitrogen Oxides", pp. 17-22, Catal. Soc. Japan (1990).

[4] W. Held, A. Konig, T. Richter and L. Puppe, SAE Paper 900, 469 (1990).

[5] J. Valyon and W.K. Hall., J. Catal., 143 (1993) 520.

[6] A.P. Ansell, A.F. Diwell, S.E. Colunski, J. W. Hayes, R.R. Rajaran, T.J. Truex and A.P. Walker, Appl. Catal. B, 2 (1993) 101.

[7] F. Witzel, G.A. Sill and W.K. Hall, J. Catal., 149 (1994) 229.

[8] Y. Li and J.N. Armor, J. Catal., 150 (1994) 376.

[9] Y. Li and J.N. Armor, Appl. Catal. B, 1 (1992) L31.

[10] J. Y. Yan, M.C. Kung, W.M.H. Sachtler and H.H. Kung, J. Catal., 172 (1997) 178. [11] M. Misono and K.Konodo, Chem. Lett., (1991) 1001. 
[12] R.T. Yang and W.B. Li, J. Catal., 155 (1995) 414.

[13] W. Li, M. Sirilumpen, R.T. Yang, Appl. Catal. B, 11 (1997) 347.

[14] X. Feng and W.K Hall, J. Catal., 166 (1997) 368.

[15] H. Hirabayashi, H. Yahiro, N. Mizuno and M. Iwamoto, Chem. Lett., (1992) 2235; $\quad$ M.

Iwamoto, H. Yahiro, H.K. Shin, M. Watababe, J. Guo, M. Konno, T. Chikahisa and T. Murayama, Appl. Catal. B, 5 (1994) L1.

[16] R. Burch and S. Scire, Appl. Catal. B, 3 (1994) 295.

[17] H. Hamada, Y. Kinataichi, M. Sasaki and T. Ito, Appl. Catal., 75 (1991) L1.

[18] R. Burch, P.J. Millington and A.P. Walker, Appl. Catal. B, 4 (1994) 65.

[19] R. Burch and T.C. Watling, Appl. Catal. B, 11 (1997) 207.

[20] K.A. Bethke and H.H. Kung, J. Catal., 172 (1997) 93.

[21] J.N. Armor, Appl. Catal. B, 4 (1994) N18.

[22] M.J. Heimrich and M.L. Deviney, SAE Paper 930, 736 (1994).

[23] A. Obuchi, A. Ohi, M. Nakamura, A. Ogata, K. Mizuno and H. Ohuchi, Appl. Catal. B, 2 (1993) 71.

[24] C.T. Kresege, M.E. Leonwicz, W.J. Roth, J.C. Vartuli and J.C. Beck, Nature, 359 (1992) 710.

[25] J.S. Beck, J.C. Vartuli, W.J. Roth, M.E. Leonowicz, C.J. Kresge, K.D. Schmitt, C.T.W. Chu, D.H. Olson, E.W. Sheppard, S.B. McCullen, J.B. Higgins and J.L. Schlenker, J. Am. Chem. Soc., 114 (1992) 10834.

[26] X.S. Zhao, G.Q. Lu and G. J. Millar, Ind. Eng. Chem. Res., 35 (1996) 2075.

[27] A. Corma, M.T. Navarro and J. Perez Pariente, J. Chem. Soc., Chem. Commun., (1994) 147.

[28] R.T. Yang, T.J. Pinnavaia, W. Li and W. Zhang, J. Catal., in press, 1997.

[29] J.M. Kim, J.H. Kwak, S. Jun and R. Ryoo, J. Phys. Chem., 99 (1995) 16742.

[30] P.T. Tanev and L.T. Vlaev, J. Colloid Interface Sci., 160 (1993) 110. 
[31] R.T. Yang, J.P. Chen, E.S. Kikkinides, L.S. Cheng and J.E. Cichanowicz, Ind.

Eng. Chem. Res., 31 (1992) 144.

[32] Y. Li and J.N. Armor, Appl. Catal. B, 1 (1992) L21.

[33] H. Hirabayashi, H. Yahiro, N. Mizuno and M. Iwamoto, Che. Lett. (1992) 2235.

[34] M.D. Amiridis, T. Zhang and R.J. Farrauto, Appl. Catal. B, 10 (1996) 203.

[35] R. Burch and T.C. Watling, Catal. Lett., 37 (1996) 51.

[36] R. Burch and T.C. Watling, Catal. Lett., 43 (1997) 19.

[37] R.B. Borade and A. Clearfield, Catal. Lett., 31 (1995) 267.

[38] G. Delahay, B. Coq and L. Broussous, Appl. Catal. B, 12 (1997) 49.

[39] A. Corma, V. Fornes and E. Palomares, Appl. Catal. B, 11 (1997) 233.

[40] M. Iwamoto, H. Yahiro, S. Shundo, Y. Yu and N. Mizuno, Appl. Catal., 69 (1991) L15.

[41] K.C.C. Kharas, H.J. Robota and D.J. Liu, Appl. Catal. B, 2 (1993) 225.

[42] T. Tanabe, T. Iijima, A. Koiwai, J. Mizuno, K. Yokota and A. Isogai, Appl. Catal.

B, 6 (1995) 145.

[43] D.J. Liu and H.J. Robota, Appl. Catal. B, 4 (1994) 155.

[44] C. Marquez-Alvarez, I. Rodriguez-Ramos, A. Guerrero-Ruiz, G.L. Haller and M. FernandezGarcia, J. Am. Chem. Soc., 119 (1997) 2905. 
Table 1 Platium dispersions and pore structure parameters of the Pt/MCM-41 catalysts

\begin{tabular}{cccccc}
\hline Catalyst & $\begin{array}{c}\text { BET Specific } \\
\text { Surface Area }\left(\mathrm{m}^{2} / \mathrm{g}\right)\end{array}$ & $\begin{array}{c}\text { Pore Volume } \\
\left(\mathrm{cm}^{3} / \mathrm{g}\right)\end{array}$ & $\begin{array}{c}\text { Pore Diameter } \\
(\mathrm{nm})\end{array}$ & $\begin{array}{c}\text { CO }(\mathrm{mg}) \\
\text { Pt dispersion }\end{array}$ & $(\%)$ \\
\hline $0.5 \%$ Pt/MCM-41 & 947 & 1.14 & 3.80 & 0.38 & 54 \\
$1 \%$ Pt/MCM-41 & 928 & 1.08 & 3.73 & 0.53 & 37 \\
$2 \%$ Pt/MCM-41 & 943 & 1.13 & 3.81 & 1.00 & 35 \\
$5 \%$ Pt/MCM-41 & 908 & 1.10 & 3.87 & 1.71 & 24 \\
\hline
\end{tabular}


Table 2 Catalytic performance of Pt/MCM-41 for selective catalytic reduction of $\mathrm{NO}$ with $\mathrm{C}_{3} \mathrm{H}_{6}$ at different temperatures

\begin{tabular}{|c|c|c|c|c|c|c|}
\hline Catalyst & Temp. $\left({ }^{\circ} \mathrm{C}\right)$ & $\begin{array}{c}\text { NO Conv. } \\
(\%)\end{array}$ & $\begin{array}{l}\text { NO Conv. } \\
\text { to } \mathrm{N}_{2}(\%)\end{array}$ & $\begin{array}{l}\text { NO Conv. } \\
\text { to } \mathrm{N}_{2} \mathrm{O}(\%)\end{array}$ & $\begin{array}{c}\mathrm{TOF} / 10^{-3} \\
\left(\mathrm{~s}^{-1}\right)\end{array}$ & $\begin{array}{c}\mathrm{C}_{3} \mathrm{H}_{6} \text { Conv. } \\
(\%)\end{array}$ \\
\hline \multirow[t]{5}{*}{$0.5 \%$ Pt/MCM-41 } & 200 & 2.0 & 2.0 & 0 & 2.7 & 1 \\
\hline & 225 & 6.0 & 3.0 & 3.0 & 8.1 & 3.1 \\
\hline & 250 & 17.0 & 6.2 & 10.8 & 23 & 11.7 \\
\hline & 275 & 54.0 & 18.7 & 35.3 & 73 & 100 \\
\hline & 300 & 37.0 & 8.5 & 28.5 & 50 & 100 \\
\hline \multirow[t]{5}{*}{$1.0 \% \mathrm{Pt} / \mathrm{MCM}-41$} & 200 & 4.0 & 2.2 & 1.8 & 3.9 & 4.0 \\
\hline & 225 & 8.0 & 4.4 & 3.6 & 7.9 & 10.2 \\
\hline & 250 & 61.0 & 16.9 & 44.1 & 60 & 100 \\
\hline & 275 & 49.0 & 15.2 & 33.8 & 48 & 100 \\
\hline & 300 & 36.0 & 11.6 & 24.4 & 35 & 100 \\
\hline \multirow[t]{5}{*}{$2.0 \% \mathrm{Pt} / \mathrm{MCM}-41$} & 200 & 13.0 & 7.2 & 5.8 & 6.8 & 14.5 \\
\hline & 225 & 33.0 & 13.8 & 19.2 & 17 & 27.0 \\
\hline & 250 & 59.0 & 15.2 & 43.8 & 31 & 100 \\
\hline & 275 & 48.0 & 13.0 & 35.0 & 25 & 100 \\
\hline & 300 & 37.0 & 10.0 & 27.0 & 19 & 100 \\
\hline \multirow[t]{5}{*}{$5.0 \% \mathrm{Pt} / \mathrm{MCM}-41$} & 200 & 7.0 & 1.3 & 5.7 & 2.1 & 3.3 \\
\hline & 225 & 20.0 & 6.7 & 13.3 & 6.1 & 13.2 \\
\hline & 250 & 63.6 & 15.4 & 48.2 & 19 & 100 \\
\hline & 275 & 61.0 & 13.2 & 47.8 & 18 & 100 \\
\hline & 300 & 47.0 & 10.6 & 36.4 & 14 & 100 \\
\hline
\end{tabular}

Conditions: $0.1 \mathrm{~g}$ of catalyst, $\mathrm{NO}=1000 \mathrm{ppm}, \mathrm{C}_{3} \mathrm{H}_{6}=1000 \mathrm{ppm}, \mathrm{O}_{2}=2 \%, \mathrm{He}=$ balance, total flow rate $=250 \mathrm{ml} / \mathrm{min}$.

TOF (turnover frequency) is defined as the number of NO molecules converted per surface Pt atom per second. 
Table 3 Main characteristics of the catalysts

\begin{tabular}{|c|c|c|c|c|c|}
\hline \multirow[t]{2}{*}{ Sample } & \multirow{2}{*}{$\begin{array}{l}\text { BET Specific } \\
\text { Surface Area } \\
\left(\mathrm{m}^{2} / \mathrm{g}\right)\end{array}$} & \multirow{2}{*}{$\begin{array}{l}\text { Pore Volume } \\
\qquad\left(\mathrm{cm}^{3} / \mathrm{g}\right)\end{array}$} & \multirow{2}{*}{$\begin{array}{l}\text { Pore Diameter } \\
\text { (nm) }\end{array}$} & \multicolumn{2}{|c|}{$\mathrm{H}_{2} / \mathrm{Cu}(\mathrm{TPR})(\mathrm{mol} / \mathrm{mol})$} \\
\hline & & & & $1^{\text {st }}$ peak & $2^{\text {nd }}$ peak \\
\hline Al-MCM-41 & 917 & 1.05 & 4.3 & - & - \\
\hline Ce-Al-MCM- & 904 & 1.09 & 4.2 & - & - \\
\hline \multicolumn{6}{|l|}{41} \\
\hline Cu-Al-MCM- & 885 & 1.03 & 4.1 & 0.41 & 0.51 \\
\hline \multicolumn{6}{|l|}{41} \\
\hline $\mathrm{Ce}-\mathrm{Cu}-\mathrm{Al}-$ & 871 & 1.03 & 4.8 & 0.36 & 0.49 \\
\hline MCM-41 & & & & & \\
\hline
\end{tabular}




\section{Figure captions}

Fig. 1 XRD patterns of the Pt/MCM-41 catalysts.

Fig.2 The effect of $\mathrm{O}_{2}$ concentration on SCR activity on 1\% Pt/MCM-41 catalyst. Reaction conditions: reaction temperature $=250^{\circ} \mathrm{C}$, catalyst $=0.2 \mathrm{~g}, \mathrm{NO}=1000 \mathrm{ppm}, \mathrm{C}_{3} \mathrm{H}_{6}=1000 \mathrm{ppm}, \mathrm{O}_{2}=0-7.8 \%, \mathrm{He}=$ balance, total flow rate $=250 \mathrm{ml} / \mathrm{min}$. (Conversion of ( ) $\mathrm{C}_{3} \mathrm{H}_{6},(\quad) \mathrm{NO},(\quad) \mathrm{NO}$ to $\mathrm{N}_{2}$ and ( ) $\mathrm{NO}$ to $\mathrm{N}_{2} \mathrm{O}$.)

Fig. 3 The effect of temperature on SCR activity on 1\% Pt/MCM-41 catalyst. Reaction conditions: catalyst $=0.2 \mathrm{~g}, \mathrm{NO}=1000 \mathrm{ppm}, \mathrm{CH}_{4}=3000 \mathrm{ppm}, \mathrm{O}_{2}=2 \%, \mathrm{He}=$ balance, total flow rate $=250$ $\mathrm{ml} / \mathrm{min}$. (Conversion of ( ) $\mathrm{CH}_{4}$ and ( ) NO.)

Fig. 4 The effect of temperature on SCR activity on 1\% Pt/MCM-41 catalyst. Reaction conditions: catalyst $=0.2 \mathrm{~g}, \mathrm{NO}=1000 \mathrm{ppm}, \mathrm{C}_{2} \mathrm{H}_{4}=1500 \mathrm{ppm}, \mathrm{O}_{2}=2 \%, \mathrm{He}=$ balance, total flow rate $=250$ $\mathrm{ml} /$ min. (Conversion of $(\quad) \mathrm{C}_{2} \mathrm{H}_{4},(\quad) \mathrm{NO},(\quad) \mathrm{NO}$ to $\mathrm{N}_{2}$ and ( ) $\mathrm{NO}$ to $\mathrm{N}_{2} \mathrm{O}$.)

Fig. 5 The effect of temperature on SCR activity on $1 \%$ Pt/MCM-41 catalyst. Reaction conditions: catalyst $=0.2 \mathrm{~g}, \mathrm{NO}=1000 \mathrm{ppm}, \mathrm{C}_{3} \mathrm{H}_{8}=1000 \mathrm{ppm}, \mathrm{O}_{2}=2 \%, \mathrm{He}=$ balance, total flow rate $=250$ $\mathrm{ml} / \mathrm{min}$. (Conversion of $(\quad) \mathrm{C}_{3} \mathrm{H}_{8},(\quad) \mathrm{NO},(\quad) \mathrm{NO}$ to $\mathrm{N}_{2}$ and ( ) $\mathrm{NO}$ to $\mathrm{N}_{2} \mathrm{O}$.)

Fig. 6 The effect of temperature on SCR activity on 1\% Pt/MCM-41 catalyst. Reaction conditions: catalyst $=0.2 \mathrm{~g}, \mathrm{NO}=1000 \mathrm{ppm}, \mathrm{C}_{3} \mathrm{H}_{6}=1000 \mathrm{ppm}, \mathrm{O}_{2}=2 \%, \mathrm{He}=$ balance, total flow rate $=250$ $\mathrm{ml} /$ min. (Conversion of ( ) $\mathrm{C}_{3} \mathrm{H}_{6},(\quad) \mathrm{NO},(\quad) \mathrm{NO}$ to $\mathrm{N}_{2}$ and ( ) $\mathrm{NO}$ to $\mathrm{N}_{2} \mathrm{O}$.) 
Fig. 7 The effect of reaction time on SCR activity on 1\% Pt/MCM-41 catalyst (a) in the absence of $\mathrm{H}_{2} \mathrm{O}$ and $\mathrm{SO}_{2}$ and (b) in the presence of $\mathrm{H}_{2} \mathrm{O}$ and $\mathrm{SO}_{2}$. Reaction conditions: reaction temperature $=225{ }^{\circ} \mathrm{C}$, catalyst $=0.2 \mathrm{~g}, \mathrm{NO}=1000 \mathrm{ppm}, \mathrm{C}_{3} \mathrm{H}_{6}=1000 \mathrm{ppm}, \mathrm{O}_{2}=2 \%, \mathrm{H}_{2} \mathrm{O}$ steam $=0$ or $5 \%, \mathrm{SO}_{2}=0$ or 500 ppm, $\mathrm{He}=$ balance, total flow rate $=250 \mathrm{ml} / \mathrm{min}$. (Conversion of $(\quad) \mathrm{C}_{3} \mathrm{H}_{6},(\quad) \mathrm{NO},(\quad)$ NO to $\mathrm{N}_{2}$ and ( ) NO to $\mathrm{N}_{2} \mathrm{O}$.)

Fig.8 XRD patterns of (a) Al-MCM-41, (b) Cu-Al-MCM-41, (c) Ce-Al-MCM-41, and (d) Ce-Cu-AlMCM-41.

Fig. 9 TPR profiles of (a) Ce-Al-MCM-41, (b) Cu-Al-MCM-41 and (c) Ce-Cu-Al-MCM-41.

Fig.10 Conversions of $\mathrm{NO}_{\mathrm{x}}$ for SCR reaction on (a) Ce-Al-MCM-41, (b) Cu-Al-MCM-41, (c) Ce-CuAl-MCM-41 and (d) Cu-ZSM-5 (data obtained from reference 11). Reaction conditions: catalyst $=0.5 \mathrm{~g}$, $[\mathrm{NO}]=\left[\mathrm{C}_{2} \mathrm{H}_{4}\right]=1000 \mathrm{ppm},\left[\mathrm{O}_{2}\right]=2 \%, \mathrm{He}=$ balance, total flow rate $=250 \mathrm{ml} / \mathrm{min}$, and space velocity $\approx$ $7500 \mathrm{~h}^{-1}$.

Fig.11 Conversions of $\mathrm{C}_{2} \mathrm{H}_{4}$ for SCR reaction on (a) Ce-Al-MCM-41, (b) $\mathrm{Cu}-\mathrm{Al}-\mathrm{MCM}-41$ and (c) Ce$\mathrm{Cu}-\mathrm{Al}-\mathrm{MCM}-41$. Reaction conditions are the same as in Fig. 3.

Fig. 12 Effect of $\mathrm{O}_{2}$ concentration on SCR activity on Ce-Cu-Al-MCM-41 catalyst. Reaction conditions: temperature $=500{ }^{\circ} \mathrm{C}$, catalyst $=0.5 \mathrm{~g},[\mathrm{NO}]=\left[\mathrm{C}_{2} \mathrm{H}_{4}\right]=1000 \mathrm{ppm}, \mathrm{He}=$ balance, total flow rate $=250$ $\mathrm{ml} / \mathrm{min}$, and space velocity $\approx 7500 \mathrm{~h}^{-1}$.

Fig. 13 Effect of $\mathrm{H}_{2} \mathrm{O}$ and $\mathrm{SO}_{2}$ on $\mathrm{SCR}$ activity over the Ce-Cu-Al-MCM-41 catalyst. Reaction conditions: temperature $=500{ }^{\circ} \mathrm{C}$, catalyst $=0.5 \mathrm{~g}$, $[\mathrm{NO}]=\left[\mathrm{C}_{2} \mathrm{H}_{4}\right]=1000 \mathrm{ppm},\left[\mathrm{H}_{2} \mathrm{O}\right]=2.3 \%$ (when 
used), $\left[\mathrm{SO}_{2}\right]=500 \mathrm{ppm}$ (when used), $\mathrm{He}=$ balance, total flow rate $=250 \mathrm{ml} / \mathrm{min}$, and space velocity $\approx$ $7500 \mathrm{~h}^{-1}$. 


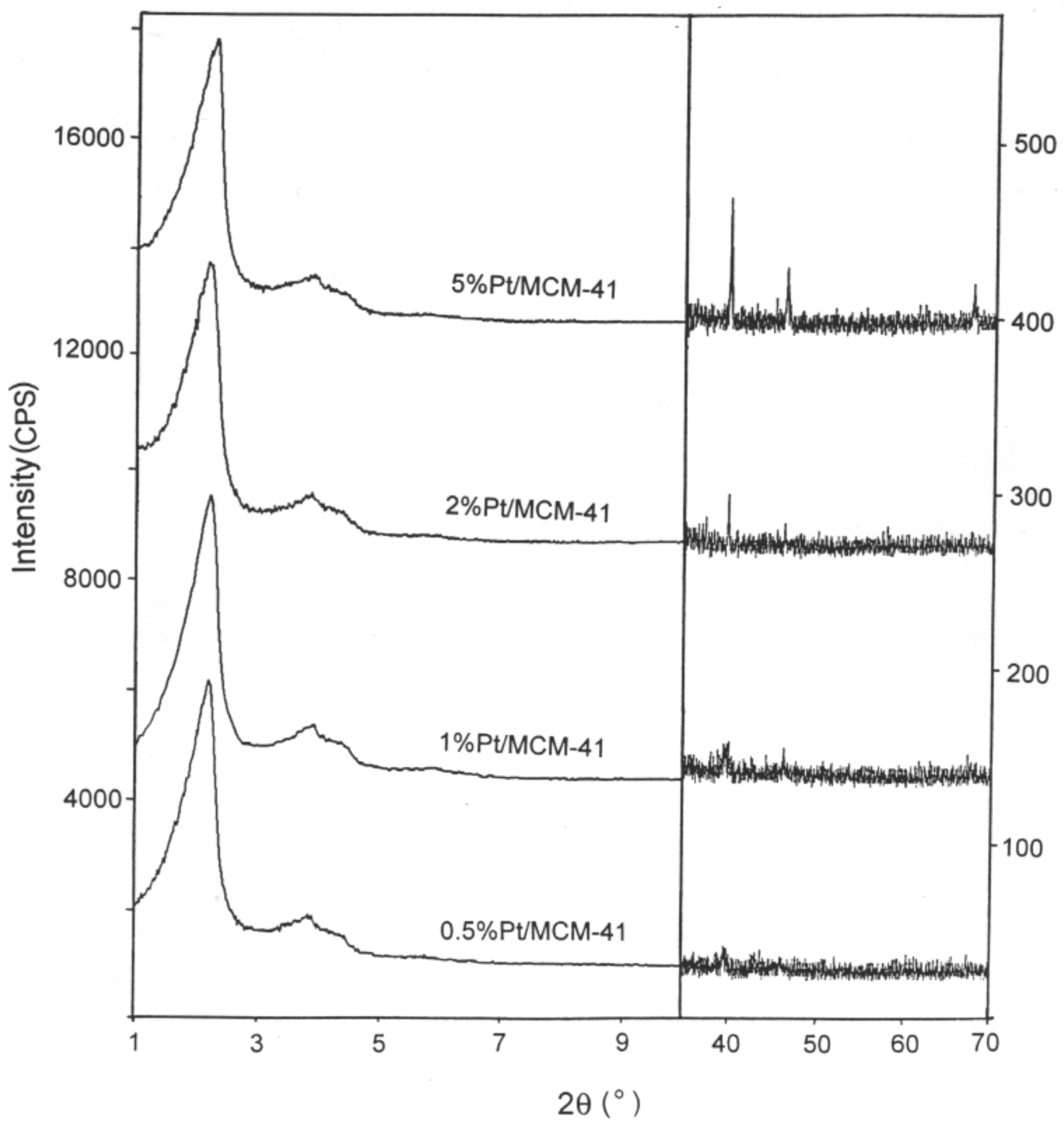




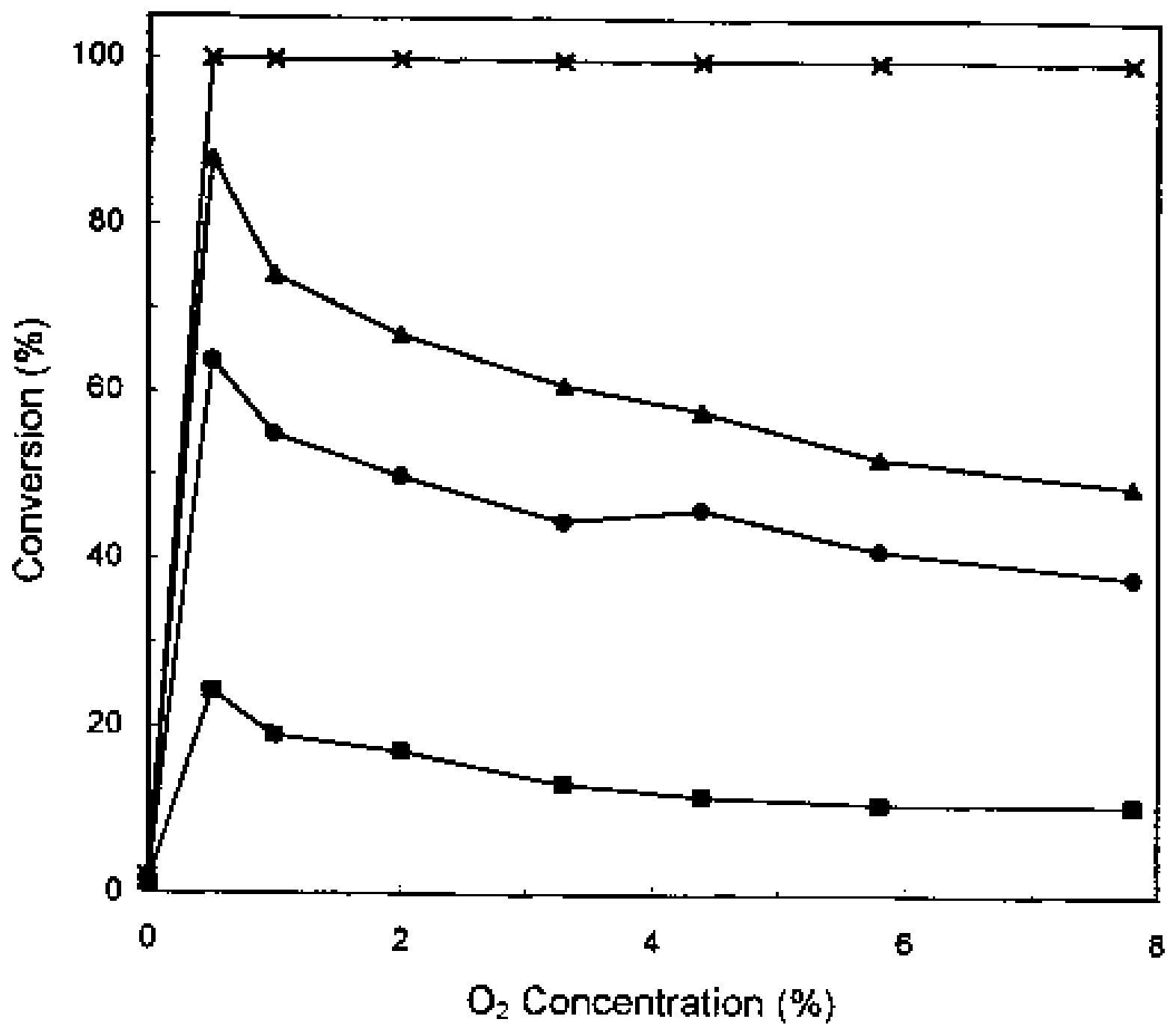




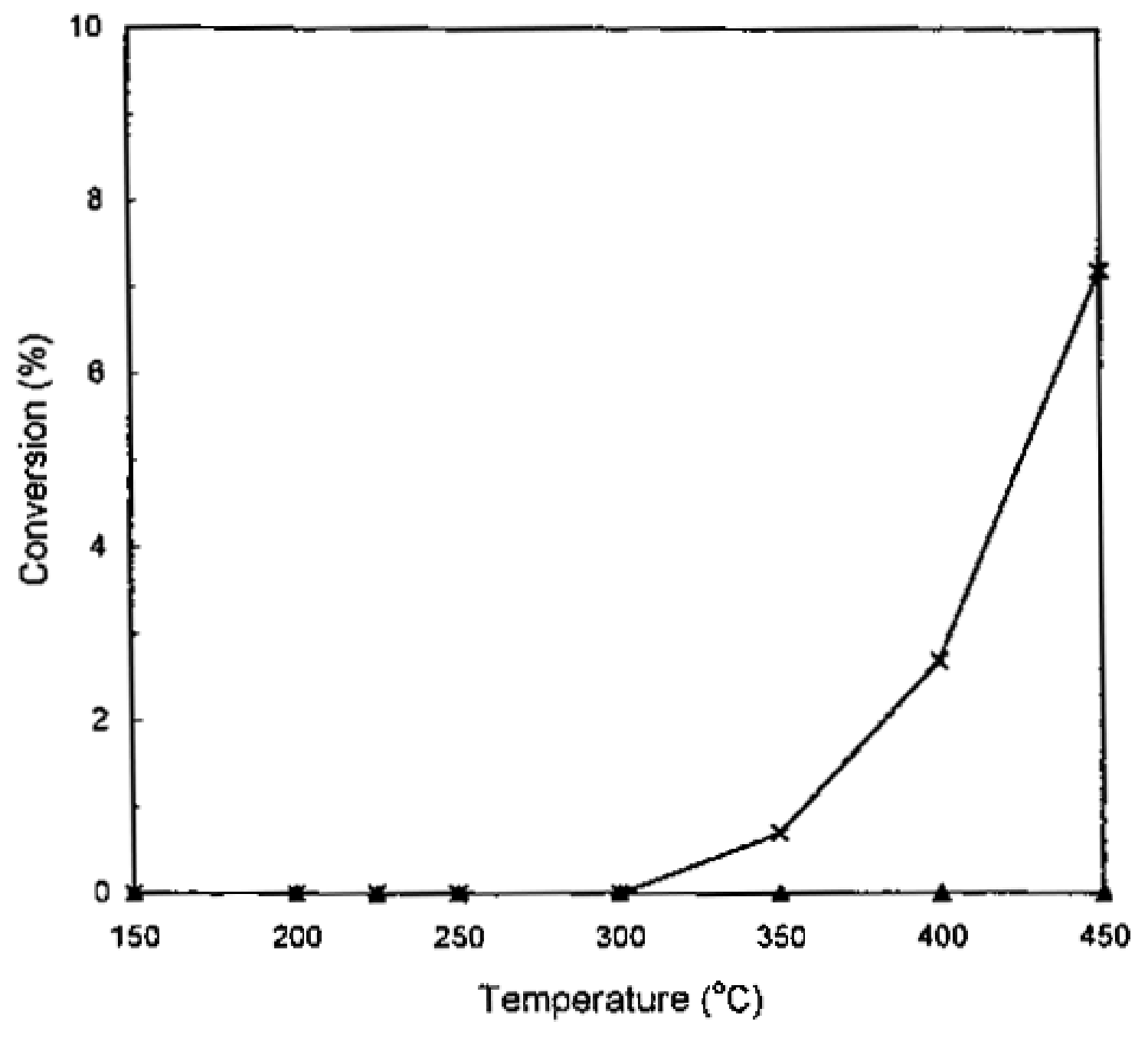




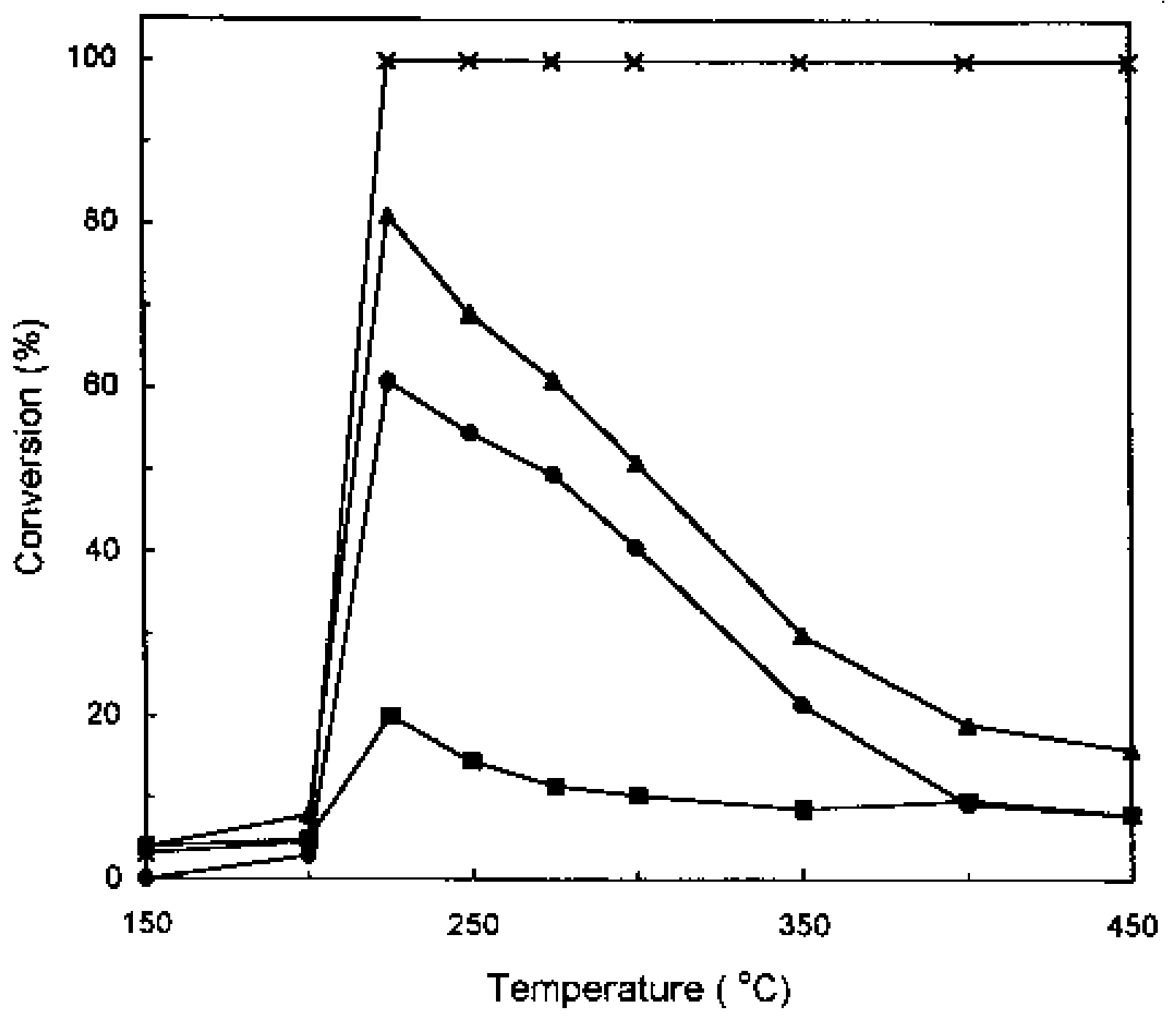




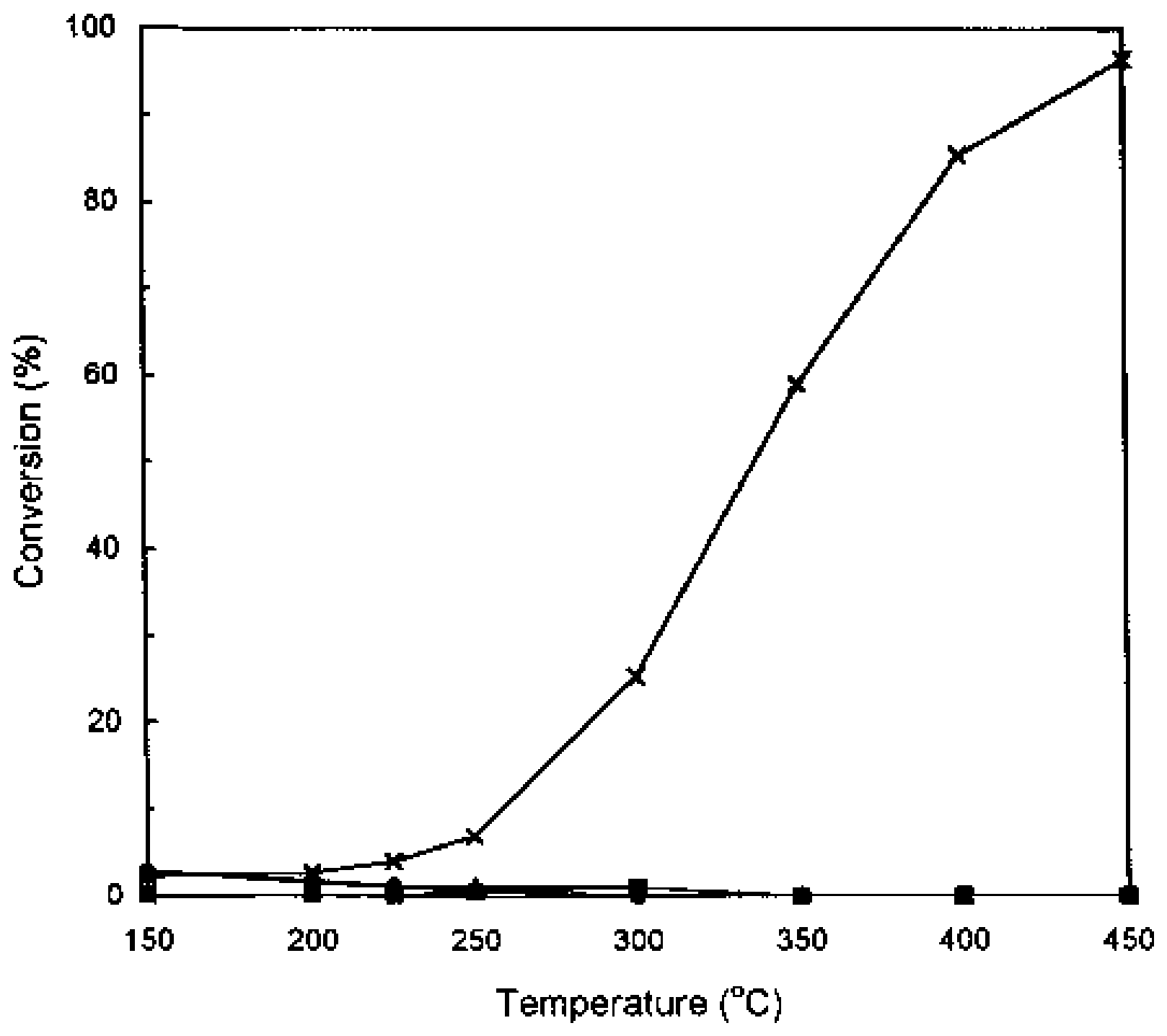




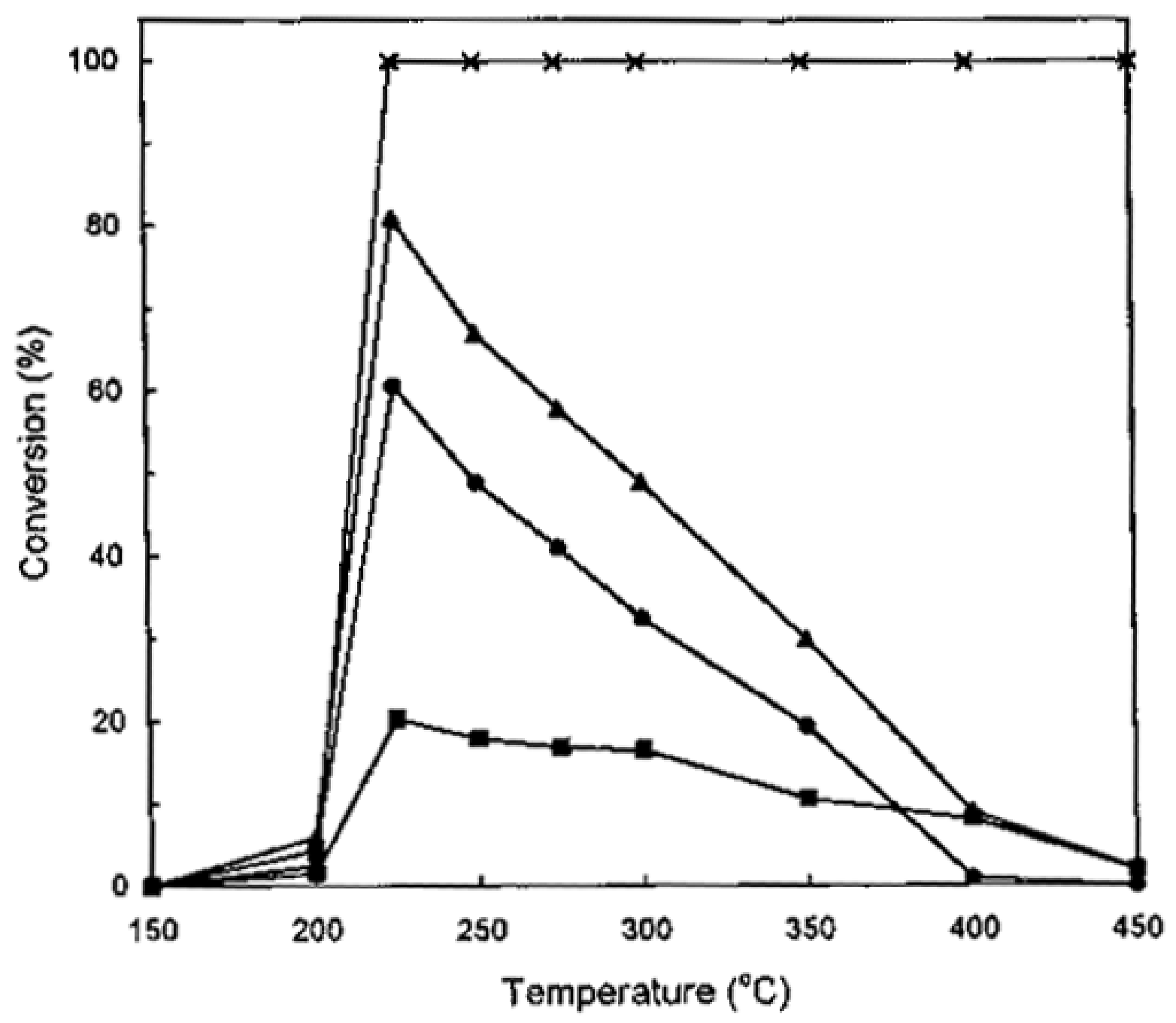




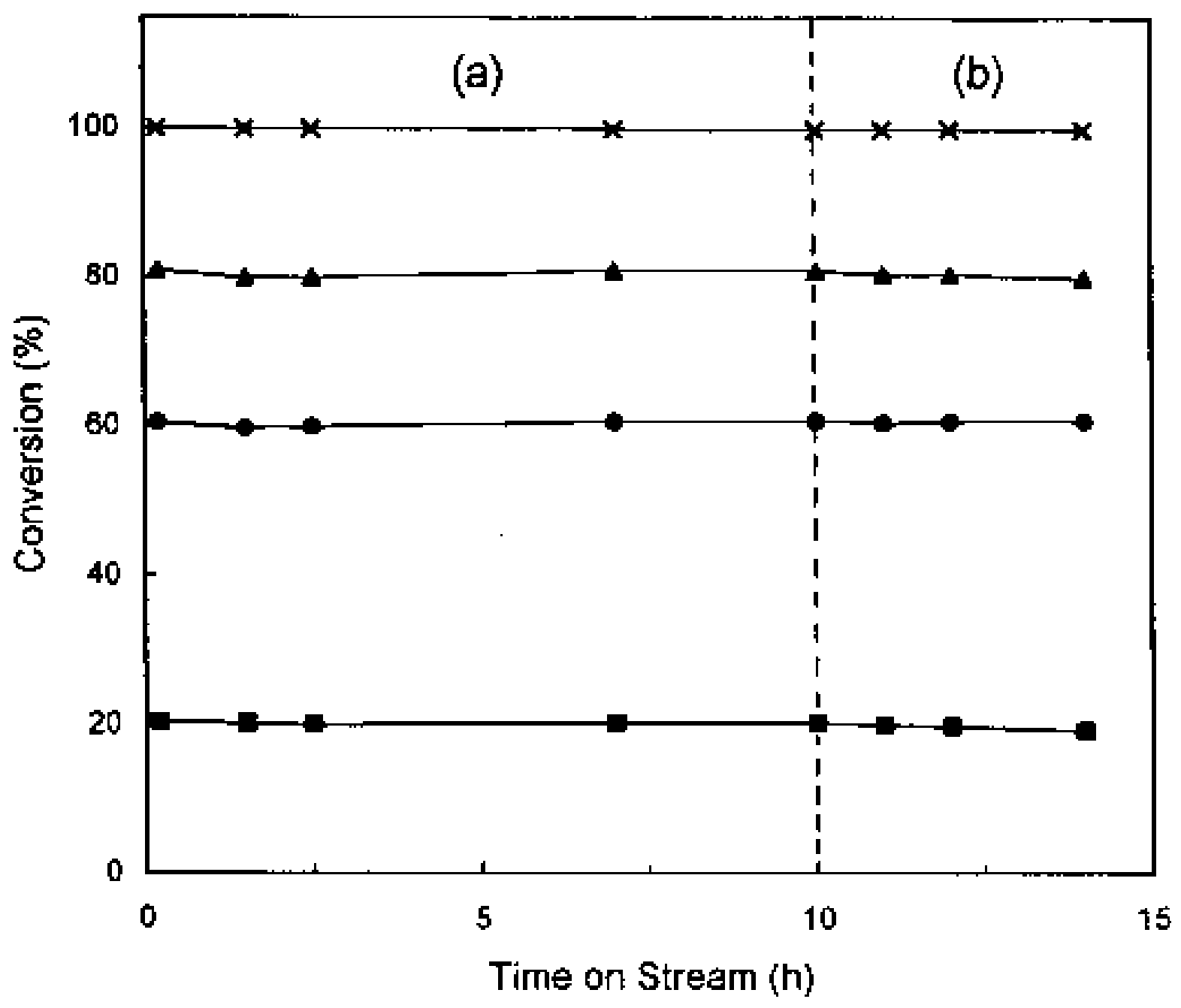




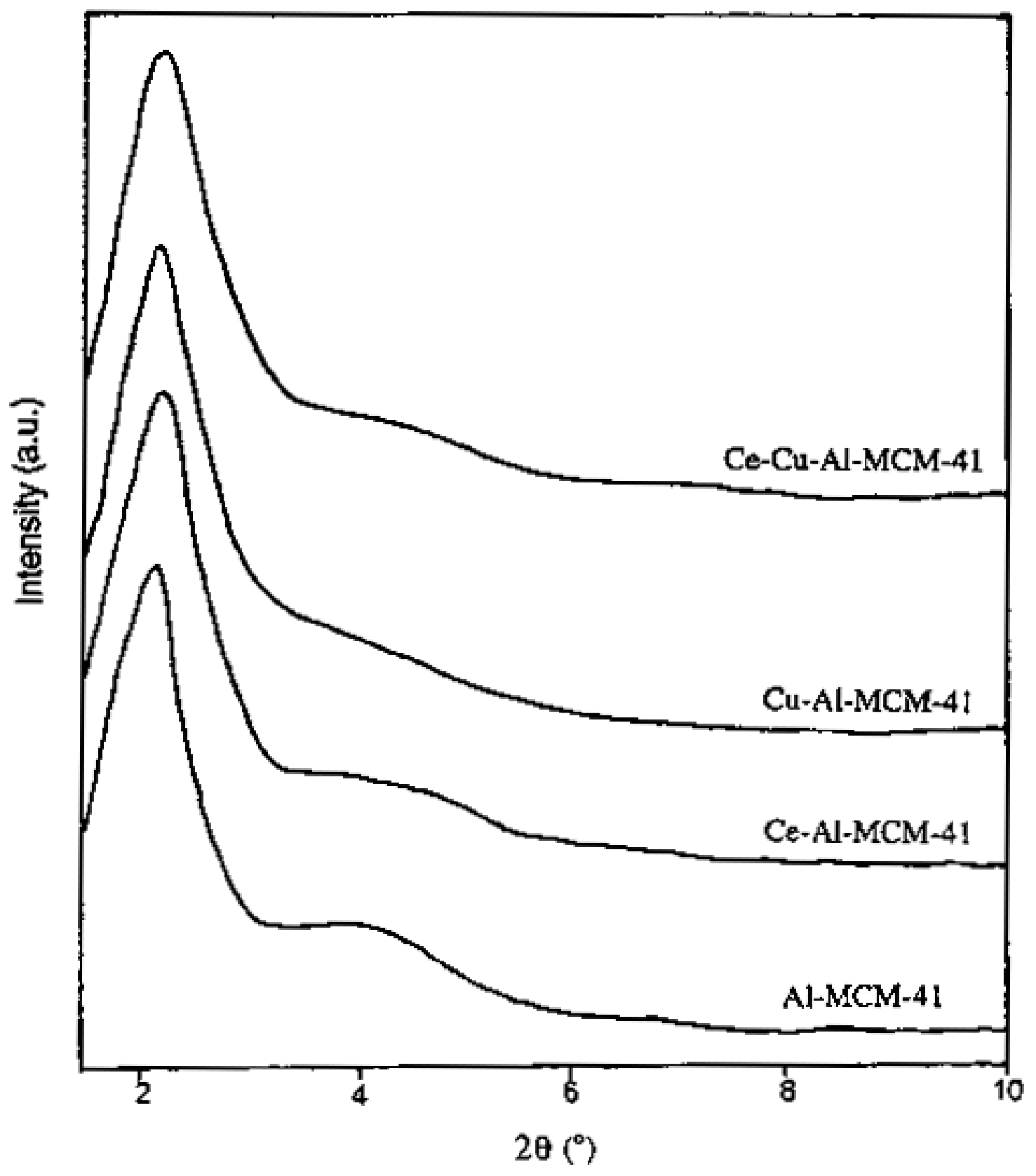




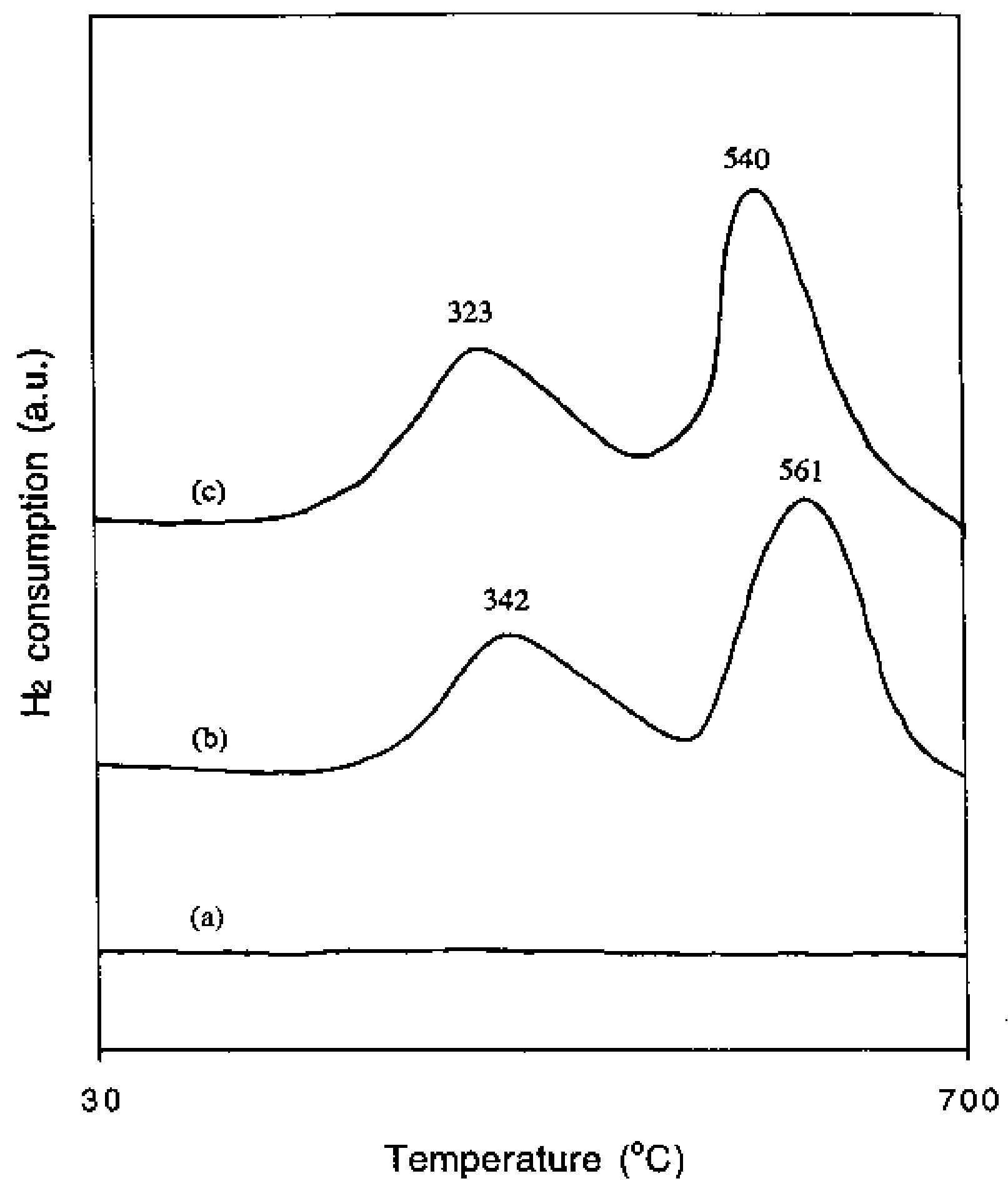




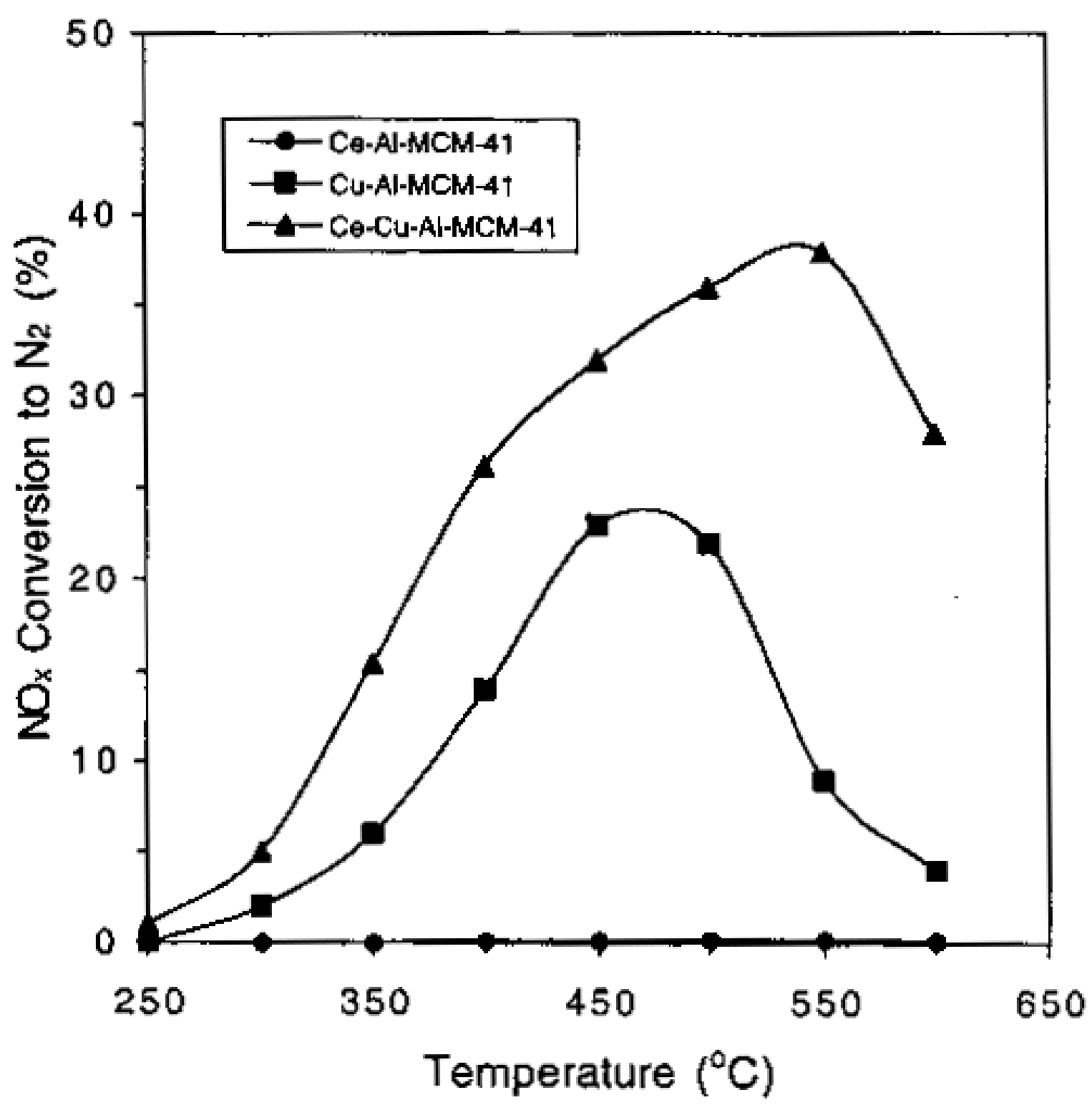




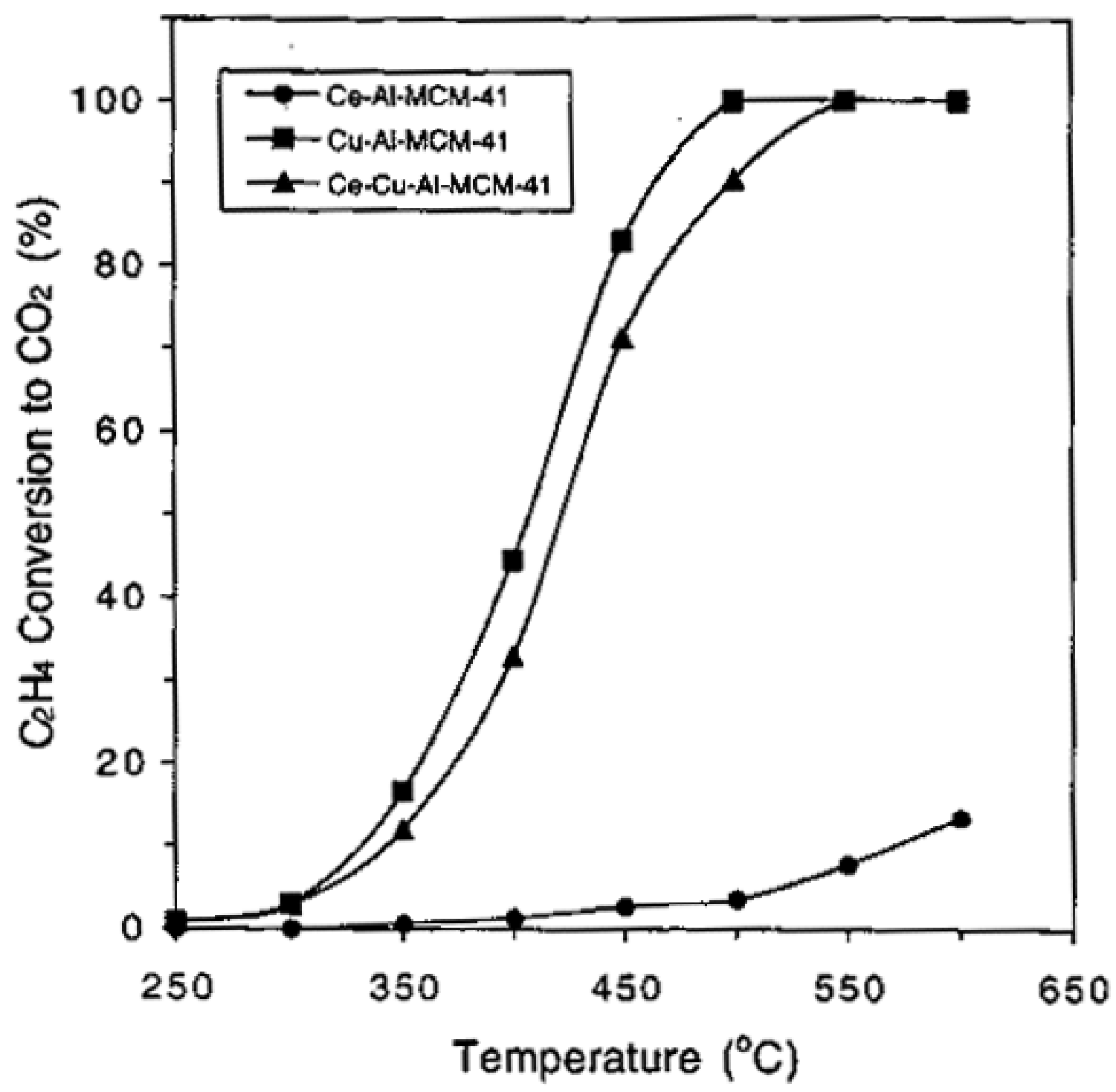




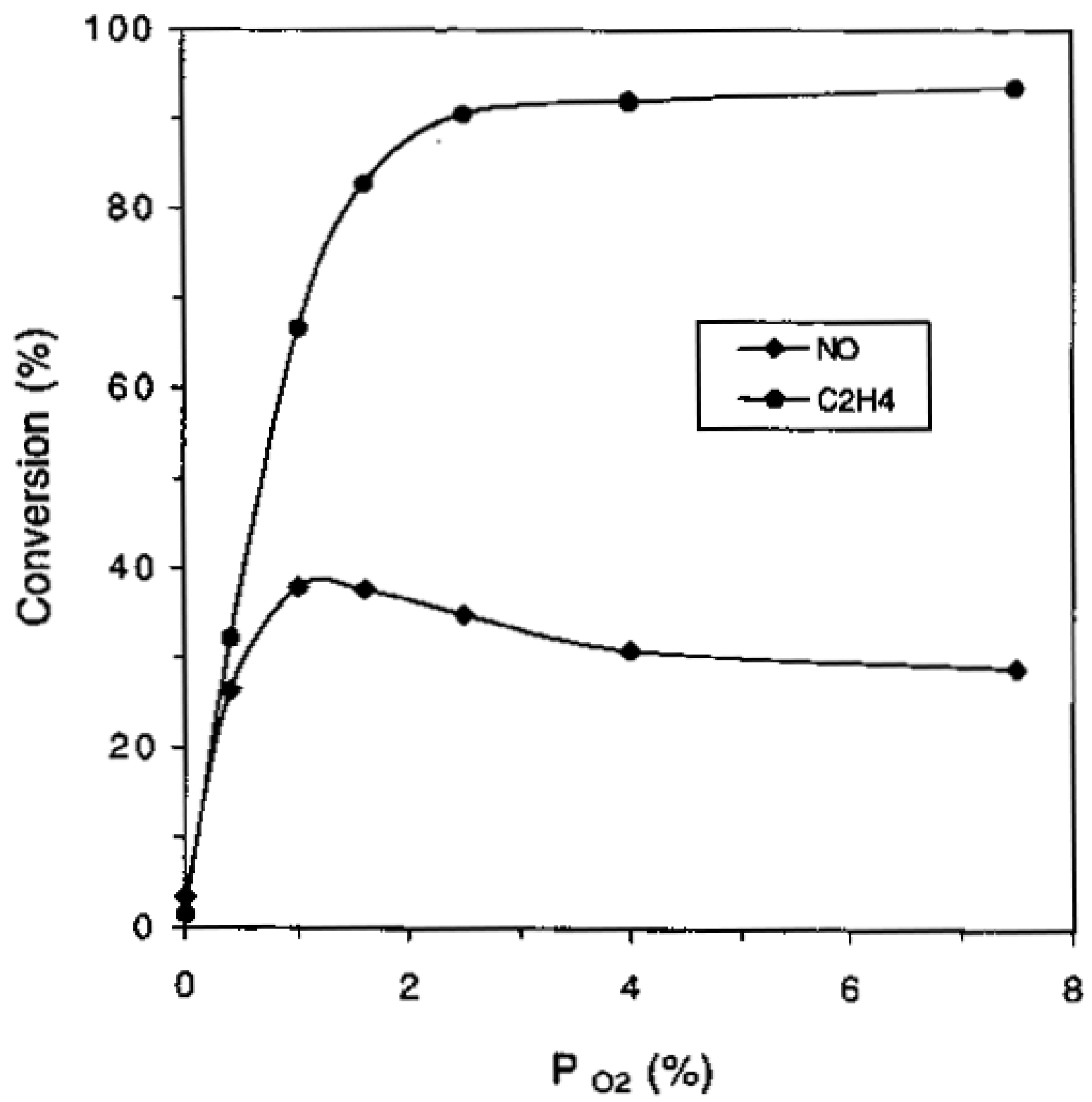




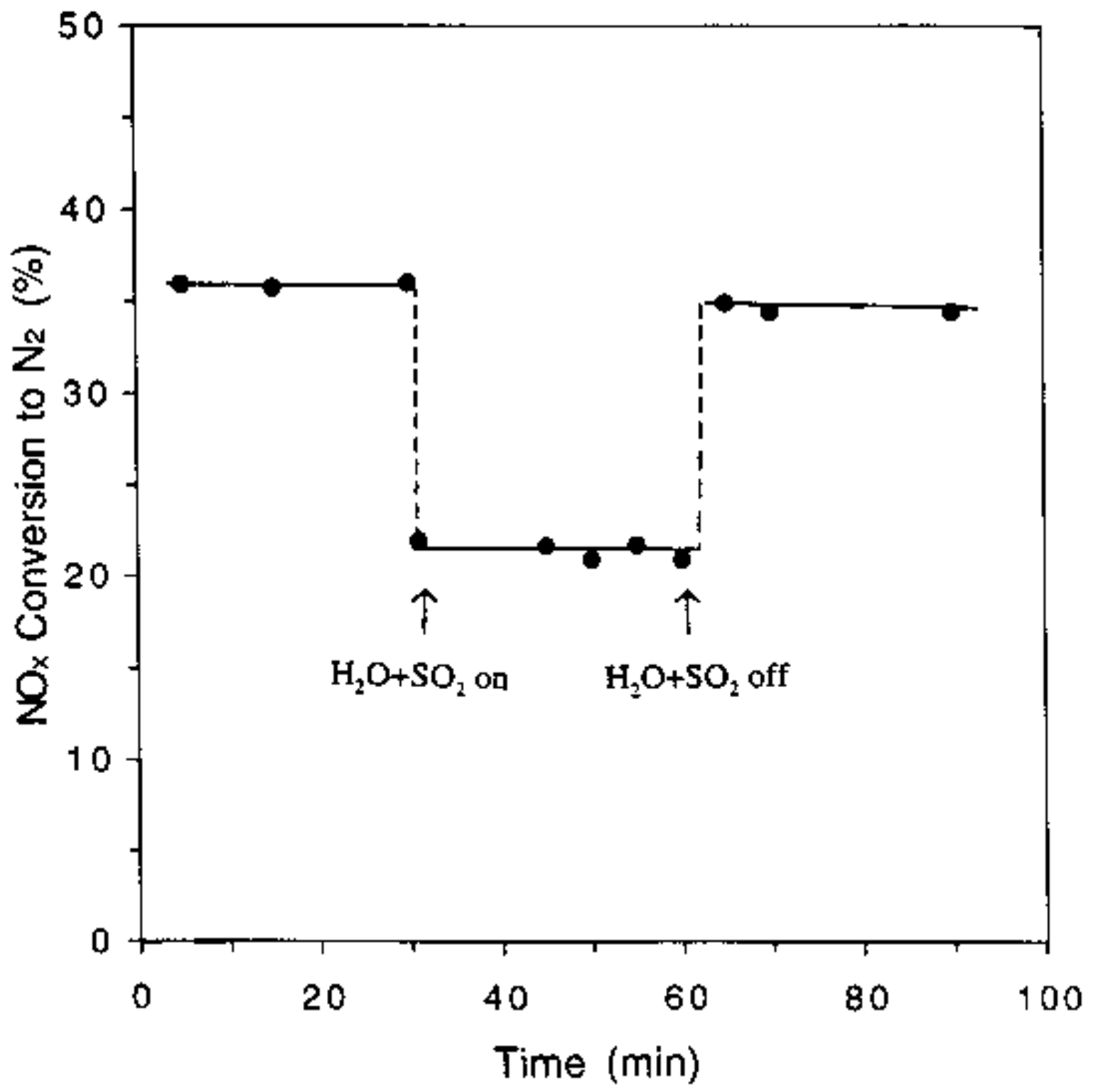

